\title{
Key Themes and Research Opportunities in Sustainable Supply Chain Management - Identification and Evaluation
}

\author{
Dr Hendrik Reefke (corresponding author) \\ School Of Management \\ Cranfield University, Cranfield, UK \\ Email: hendrik.reefke@cranfield.ac.uk \\ Dr David Sundaram \\ Department of Information Systems and Operations Management \\ The University of Auckland Business School, New Zealand \\ Email: d.sundaram@auckland.ac.nz
}

\begin{abstract}
Supply chains play an integral role in today's globalized economy. Hence, in order to truly pursue sustainable business development, the underlying dynamics and influential themes for sustainability in supply chains have to be understood. However, this area remains characterized by limited theoretical knowledge and practical application. A literature review was conducted first in order to gain an overview of available theory and to develop initial categorizations. In the next step, the insights of supply chain and sustainability experts were gathered via an exploratory Delphi study conducted online over three rounds. A set of key themes (planning, execution, coordination, and collaboration) and associated research opportunities (within the categories of governance, risk, compliance, performance management, and the sustainability dimensions) were synthesized and evaluated according to their relative importance based on the experts' opinions. By relating these results to existing literature, this study confirms, questions and extends knowledge on sustainable supply chain management. The identified themes are integral for the management and performance of sustainable supply chains. They provide structure to the field and offer a prioritisation of sustainability initiatives that can be applied prescriptively by the practitioner. The future research opportunities are further enfolded in a categorised research agenda, driving the theoretical as well as practical development of the field.
\end{abstract}

Keywords: Supply Chain Management, Sustainability, Delphi, Future Research, Governance, Risk, Performance 


\section{Introduction}

Sustainability in business environments refers to the need to address and manage issues on economic, social, and environmental dimensions in a balanced and integrated manner (Elkington, 1998). The requirement for sustainable development is widely recognised by regulative bodies, companies, and consumers and can be defined as "development that meets the needs of the present without compromising the ability of future generations to meet their own needs" (WCED, 1987). It thus requires a global view at development, emphasising the relationships between environmental improvement and social equitability through sustainable economic growth. At this critical juncture, supply chains (SC) are well-positioned to support sustainable development due to their wide-ranging impacts and influences. Decision makers in SCs are therefore tasked with initialising strategic sustainability orientations and operational shifts. SCs and sustainability requirements are both characterised by complex interactions which have to be understood and properly integrated in order to foster sustainable supply chain management (SSCM). Unsustainable, and often unaccounted, SC impacts can usually not be attributed to only one SC member but are rather the product of dynamic interactions within the chain. While some SC practices may be considered more sustainable, their focus is generally on isolated issues and not generalizable across different $\mathrm{SC}$ environments. The current understanding of SSCM is limited with regard to overviews and categorisations of crucial elements and requirements for sustainable SC development. This paper makes contributions in this context in order to guide academics and practitioners in focussing their efforts. Furthermore, the paper summarises, proposes and prioritises research avenues to advance the field.

\subsection{Research Motivation and Objectives}

Business success increasingly depends on efficient supply chain management (SCM) (Chen \& Paulraj, 2004) since significant proportions of business revenues are generated through the SC (Lambert \& Cooper, 2000). It is therefore vital that sustainability considerations be integrated into SC functions such as procurement, manufacturing, distribution, warehousing, usage, recycling and disposal (Jayaraman, Klassen, \& Linton, 2007). These requirements are being pushed to the fore by stricter regulations, customer interests, reputation effects, competitive forces, and public pressures (Esty \& Winston, 2006; Lieb \& Lieb, 2010; Linton, Klassen, \& Jayaraman, 2007) and further emphasised by aspects such as global warming, resource limitations, emissions, and health issues. SSCM also deserves special attention in light of dynamic market developments, e.g. globalisation, dependencies on foreign markets and imports, outsourcing, risks of SC disruption, or economic recessions (Lee, 2010). The economic, political, social, and ethical pressures and demands of Corporate Social Responsibility (CSR) identified by Garriga and Melé (2004) are all present and motivate SSCM. However, economic pressures and priorities often override such demands. 
Knowledge in SSCM is based on developments in various related fields including SCM, logistics, operations management, environmental management, social sciences, marketing, and strategy (Badurdeen, Metta, \& Gupta, 2009; Carter \& Rogers, 2008). Sustainability related research has become mainstream (Corbett \& Klassen, 2006) and also SSCM has matured considerably (Seuring \& Müller, 2008b; Seuring, Müller, Westhaus, \& Morana, 2005; Winter \& Knemeyer, 2013). However, truly acknowledged theories of SSCM do not exist and are absent in SC practice. Practical implementation has proven difficult and research has only started to investigate the requirements and multiple aspects of practices to support SSCM (Wagner \& Svensson, 2010). Focussed research is therefore required in order to exploit the sustainability opportunities in SCs (Carter \& Easton, 2011; Colicchia, Melacini, \& Perotti, 2011; Dey, LaGuardia, \& Srinivasan, 2011; Halldórsson \& Kovács, 2010; Pagell \& Wu, 2009; Winter \& Knemeyer, 2013). That is, SSCM research has remained limited in focus and there is a lack of theory development backed by rigorous research approaches (Carter \& Easton, 2011; Winter \& Knemeyer, 2013). Several recent review articles have been targeted at delineating the current understanding of SSCM and at deriving associated research directions. These studies represent valuable additions to literature, but are often characterised by a narrow focus. This paper extends these efforts by combining the insights from literature with the inputs from practicing experts in the field. Prior research has tended to be rather theoretical and to redress this we seek to hear the voice of experts who have a strong professional grounding in SSCM and related areas. It is the aim to create a more comprehensive overview of central themes in SSCM as well as a research agenda by categorising research avenues, deriving importance evaluations, and by pointing towards methodological options. Thus, this article has the following key objectives:

Research Objective 1: Develop key themes that are central to the practice and research of SSCM structured according to elements essential to the management of SCs.

Research Objective 2: Develop a research agenda for SSCM by synthesising research recommendations from literature and further extending and categorising these by utilising experts from the field.

\subsection{Structure of this Article}

Following the outline of the research motivation and objectives for this study, the article progresses with an overview of building blocks in supply chain management (SCM) and synthesises research recommendations for SSCM from seminal articles. These reviews provide a foundation for this study and also support the categorisation of results. The focus then turns to an exploratory Delphi study conducted over three rounds which is targeted at gaining a more detailed understanding of crucial elements in SSCM. Study participants are experts in related fields and their aggregated insights leads to the identification and evaluation of key themes and additional research opportunities in SSCM. Detailed discussions of the study findings in light of current literature illustrate their usefulness and prescriptive explanations are provided. Concluding comments reflect on how these findings contribute to the understanding of SSCM and how they can be leveraged by SC scholars. 


\section{Literature Review}

In order to understand the structure and results of this study, it is necessary to review building blocks of SCM and illustrate their relevance for sustainable development. This review starts with an initial conceptualisation of categories and elements that are influential in SSCM in order to provide a foundation for Research Objective 1. This is followed by a review of research recommendations in the field in order to gain initial insights for Research Objective 2. This synthesis is subsequently utilised and extended by the findings of the Delphi study.

\subsection{Deriving Supply Chain Categories}

A range of definitions for SCM exist, emphasising different perspectives (Mentzer et al., 2001). In addition, a variety of managerial frameworks have been proposed aimed at structuring the activities and processes prevalent in SCM (Moberg, Vitasek, Stank, \& Pienaar, 2008). Similarly, different conceptualisations of SSCM have been suggested. Hassini et al (2012) created a framework around essential SC functions, relating mainly to planning and execution. Like other scholars we support the notion that SSCM requires a wider focus incorporating SC planning and execution but also extending towards SC coordination and collaboration (Ahi \& Searcy, 2013; Winter \& Knemeyer, 2013). SC coordination focuses on coordinating group tasks while SC collaboration focuses on information exchange between SC members (Schummer \& Lukosch, 2013). Hence, these were utilised as guiding categories in this study. Figure 1 offers a useful summary of this conceptualisation by grouping common activities in SCM along four key categories, namely planning, execution, coordination, and collaboration.

\begin{tabular}{|c|c|c|c|c|c|c|c|}
\hline $\begin{array}{l}\text { Supply } \\
\text { Chain } \\
\text { Planning }\end{array}$ & $\begin{array}{l}\text { Supply } \\
\text { Chain } \\
\text { Design }\end{array}$ & $\begin{array}{l}\text { Demand } \\
\text { Planning }\end{array}$ & $\begin{array}{l}\text { Supply } \\
\text { Planning }\end{array}$ & $\begin{array}{l}\text { Distribution } \\
\text { Planning }\end{array}$ & $\begin{array}{l}\text { Production } \\
\text { Planning }\end{array}$ & \multicolumn{2}{|c|}{$\begin{array}{l}\text { Forward/Reverse } \\
\text { Transportation } \\
\text { Planning }\end{array}$} \\
\hline $\begin{array}{l}\text { Supply } \\
\text { Chain } \\
\text { Execution }\end{array}$ & $\begin{array}{l}\text { Materials } \\
\text { Management }\end{array}$ & $\begin{array}{c}\text { Manu- } \\
\text { facturing }\end{array}$ & $\begin{array}{c}\text { Order } \\
\text { Promising } \\
\text { and Delivery }\end{array}$ & $\begin{array}{l}\text { Warehou } \\
\text { Managem }\end{array}$ & \multicolumn{2}{|c|}{$\begin{array}{c}\text { Forward/Reverse } \\
\text { Transportation } \\
\text { Execution }\end{array}$} & \begin{tabular}{|c} 
Foreign \\
Trade/Legal \\
Services
\end{tabular} \\
\hline $\begin{array}{c}\text { Supply } \\
\text { Chain } \\
\text { Coordination }\end{array}$ & \multicolumn{2}{|c|}{$\begin{array}{l}\text { Supply Chain Event } \\
\text { Management }\end{array}$} & $\begin{array}{l}\text { Supply Chain } \\
\text { Performance } \\
\text { Management }\end{array}$ & \multicolumn{2}{|c|}{$\begin{array}{l}\text { Fulfillment } \\
\text { Coordination }\end{array}$} & \multicolumn{2}{|c|}{$\begin{array}{c}\text { Returns } \\
\text { Coordination }\end{array}$} \\
\hline $\begin{array}{c}\text { Supply } \\
\text { Chain } \\
\text { Collaboration }\end{array}$ & \multicolumn{2}{|c|}{ Collaboration Processes } & \multicolumn{2}{|c|}{ Supply Chain Integration } & \multicolumn{3}{|c|}{$\begin{array}{l}\text { Waste/Recycling } \\
\text { Management }\end{array}$} \\
\hline
\end{tabular}

Figure 1: Supply Chain Management Elements (adapted from S. Bansal, 2009)

Following the aim of this paper, concepts applicable from an academic viewpoint and for SC practice were sought. These categories are well established in academic discussions (Arshinder \& Deshmukh, 2008; Simatupang \& Sridharan, 2005; Stadtler, 2005) and more practitioner oriented sources 
(CSCMP, 2009; SAP AG, 2011). The following sections elaborate on their origin within SCM and their connections and relevance for sustainable SCs. The SC categories established here are then utilised for the subsequent Delphi and provide the underlying structure for unfolding key themes in SSCM.

\subsubsection{Planning}

SCs are complex structures that can span across multiple tiers of suppliers and customers (Cooper, Ellram, Gardner, \& Hanks, 1997). Hence, initial as well as ongoing SC design and planning activities are of crucial importance. Planning decisions and developed processes impact a SC on strategic, tactical, as well as operational levels. Typical examples include demand, capacity and material requirements planning, as well as production, network and distribution planning (Stadtler, 2005). Strategic network design is performed with a long-term perspective, while planning decisions regarding purchasing, production, distribution and demand fulfilment are taken in the mid to shortterm (Meyr, Wagner, \& Rohde, 2008).

The importance of proper planning for building a sustainable SC cannot be overstated and a holistic long term strategy is likely to be required (Carter \& Rogers, 2008). However, the importance of SC planning and design is unfortunately often ignored in practice (Liu, Vazquez-Brust, \& Sarkis, 2014). It is thus crucial to identify the themes that can enable proper SSCM planning.

\subsubsection{Execution}

SCs are driving forces behind competitive advantage (Carter \& Rogers, 2008; Jayaraman et al., 2007; Seuring \& Müller, 2008b), making effective execution a necessity. SC execution is concerned with managing orders, inventories, material flows, manufacturing and delivery, as well as warehousing and forward/reverse transportation. SC execution translates planning decisions into practice and supports short term decisions regarding procurement, production, distribution, and sales (Meyr et al., 2008).

Sustainability impacts may primarily occur or become visible during SC execution, e.g. manifested through distribution activities or customer interactions. Efficient SSCM execution is highly reliant on preceding steps and prerequisites, i.e. SC planning, coordination as well as collaboration. However, the transition of strategic sustainability priorities into executable SC practices remains challenging (Winter \& Knemeyer, 2013).

\subsubsection{Coordination}

SC coordination is about maintaining control over SC processes such as procurement, production, and distribution through monitoring of operations, analysis, and process optimisation. Coordination issues occur between internal business functions, across SC functions, and at SC interfaces (Arshinder \& Deshmukh, 2008). SCM is accomplished through SC processes that cut across functional boundaries. Functions are occupations or departments that concentrate skill, in contrast processes tend to be cross functional and are measurable, countable, with valuable outcomes for customers of that process (Sharp \& McDermott, 2009). Coordination addresses the configuration of 
information flows and planning activities. It should occur at various intersections, e.g. in transitions from SC planning to execution, in order remove information asymmetry and ensure improved outcomes (Kilger, Reuter, \& Stadtler, 2008).

SSCM requires the coordination of internal sustainability requirements with those of external SC stakeholders. Knowledge and targeted use of applicable tools and methods are required since sustainability principles are often not coordinated SC wide (KPMG, 2011; Turner \& Houston, 2009).

\subsubsection{Collaboration}

Collaboration is about building and maintaining SC relationships in order to create competitive advantages. In a collaborative SC, operations are jointly planned and executed in order to improve communications and information flows, increase SC efficiency and visibility, and decrease costs (Simatupang \& Sridharan, 2002). It builds on SC coordination but extends passive data exchange towards proactive activities such as common planning and synchronisation of processes. Collaborative planning, forecasting and replenishment (CPFR) is a well-known approach that fosters collaborative SC relationships (Skjoett-Larsen, Thernøe, \& Andresen, 2003).

SSCM essentially refers to a collaborative SC environment which facilitates and fulfils the requirements for sustainability. Collaborative practices are necessary to facilitate long term sustainability goals and remove opposition to change (Munro, 1995; Pagell \& Wu, 2009). They have furthermore been associated with successful SSCM (Gold, Seuring, \& Beske, 2010; Zhu \& Sarkis, 2006), warranting further investigations.

\subsection{Research Recommendations from Literature}

In order to shape a research agenda for SSCM, it is advisable to summarise research recommendations from literature as a first step. The field of SSCM has expanded quickly as evidenced by the increasing number of reviews (e.g. Ahi \& Searcy, 2013; Ashby, Leat, \& HudsonSmith, 2012; Carter \& Easton, 2011; Carter \& Rogers, 2008; Hassini et al., 2012; Seuring, 2013; Seuring \& Müller, 2008b; Winter \& Knemeyer, 2013). Between 1995 and 2010 the number of articles increased significantly (Winter \& Knemeyer, 2013) and authors have outlined respective research directions. In order to create a summary that captures and reflects the various research directions in the field accurately, several recent literature reviews in SSCM were utilised. The recommendations that were synthesised are based on examinations of the field from different angles. Ahi \& Searcy (2013) analyse definitions of SSCM along key characteristics while Seuring (2013) explores the application of modelling approaches. Winter \& Knemeyer (2013) then provide a snapshot of the field and specifically suggest avenues for future enquiries. Ashby et al. (2012) perform a structured review with a focus on social and environmental aspects while Hassini et al. (2012) focus especially on performance metrics. Carter \& Easton (2011) finally concentrate on a number of principal journals to derive future research directions. 
Table 1: Overview of Research Recommendations from Literature

\begin{tabular}{|c|c|}
\hline Source & Research Recommendation \\
\hline $\begin{array}{l}\text { (Ahi \& } \\
\text { Searcy, } \\
\text { 2013) }\end{array}$ & $\begin{array}{l}\text { xploring the implications of and potential resolutions to the many differences in the published definitions of } \\
\text { SCM provides an avenue for future research. }\end{array}$ \\
\hline $\begin{array}{l}\text { (Seuring, } \\
2013)\end{array}$ & $\begin{array}{l}\text { How can the social dimension be integrated into respective models? } \\
\text { Interrelation among all three dimensions of sustainability and models thereof. } \\
\text { How does environmental and social performance impact supply chain performance? } \\
\text { How can contracts and supply chain cooperations be understood further, so that sustainability issues are not just } \\
\text { seen as trade-offs? } \\
\text { Establish the links to the literature on strategic supply chain design, supply chain performance and collaboration } \\
\text { literature. }\end{array}$ \\
\hline $\begin{array}{l}\text { (Winter \& } \\
\text { Knemeyer, } \\
\text { 2013) }\end{array}$ & $\begin{array}{l}\text { A more multidisciplinary approach may support a more holistic examination of SSCM, e.g. synergies across the } \\
\text { risk management and sustainability literature as well as linkages between SSCM activities and outsourcing or } \\
\text { lean activities. } \\
\text { An integration of social network theory into the study of sustainability offers potential. } \\
\text { How do sustainability efforts influence supplier segmentation activities and/or the development of product and } \\
\text { service agreements between companies? } \\
\text { Research should look beyond a focal firm but instead at the role of interacting with external parties in this area in } \\
\text { order to evaluate the activities related to the supply chain processes and network structure as it relates to the } \\
\text { potential economic impact for a firm. } \\
\text { Research should look at the connection between managerial components and sustainability efforts, in an effort } \\
\text { to better understand how managerial practices can influence the success or failure of sustainability initiatives. } \\
\text { Companies need a concrete toolbox that supports their efforts to reach their sustainability objectives, e.g. } \\
\text { structural management components and adequate control mechanisms. } \\
\text { The development and validation of appropriate metrics and scorecards in support of SSCM offers an opportunity } \\
\text { for highly applicable research. } \\
\text { The development of estimation tools and techniques to provide financial justification for sustainable activities. } \\
\text { Investigate how suppliers can engage their customers on sustainability initiatives or to better understand how } \\
\text { sustainable supply chain initiatives can be used to enhance a company's brand and/or marketing efforts. }\end{array}$ \\
\hline & $\begin{array}{l}\text { A key research direction for progressing SSCM would be the role of supply chain relationships in achieving } \\
\text { sustainability. } \\
\text { Life cycle analysis and the concept of closed loop supply chains could provide a more connected view of } \\
\text { sustainability in supply chains. } \\
\text { A more holistic and relational viewpoint offers the greatest potential for progressing SSCM from "greening" to a } \\
\text { "virtuous circle" that addresses sustainability at all stages and interactions. } \\
\text { Translating SSCM theory developed through more focused approaches into actual supply chain practice should } \\
\text { be a key priority. }\end{array}$ \\
\hline $\begin{array}{l}\text { (Hassini et } \\
\text { al., 2012) }\end{array}$ & $\begin{array}{l}\text { More attention should be given to industry-specific research on SSCM. } \\
\text { Pricing, as part of the value proposition to the customer, should be more strongly emphasized. } \\
\text { Address inventory management within sustainable supply chains since traditional inventory models focus on } \\
\text { economic aspects. } \\
\text { How should SMEs and large firms approach investment in and adoption of sustainable practices? } \\
\text { Research into performance assessments of sustainable supply chain, e.g. metrics, composite indicators, } \\
\text { compatibility with existing theory. }\end{array}$ \\
\hline $\begin{array}{l}\text { (Carter \& } \\
\text { Easton, } \\
\text { 2011) }\end{array}$ & $\begin{array}{l}\text { Research to dig deeper into individual industries as sampling frames to identify specific types of sustainability } \\
\text { activities and assess the applicability of specific theories. } \\
\text { Study the sustainability characteristics of service supply chains. } \\
\text { Investigate the relationship between company environmental and social performance versus economic } \\
\text { performance. } \\
\text { The relationship between regulatory compliance and economic performance across members of a supply chain. } \\
\text { Examine how bounded rationality and perceptions of opportunism within the context of SSCM impact the } \\
\text { decision to source domestically or even locally, as opposed to internationally, and how supply chain governance } \\
\text { structures are affected } \\
\text { Examine supply chain management employees as internal stakeholders, and how employee attitudes and } \\
\text { commitment to organizations might differ based on differing levels of SSCM. } \\
\text { Examination of the biases that can enter the individual decision-making process, and how these biases can } \\
\text { impact the efficacy of SSCM initiatives. } \\
\text { Investigation of how individual managers can influence and gain the commitment of key internal stakeholders to } \\
\text { bring SSCM projects to fruition. } \\
\text { Based upon theories developed in adjacent fields, use conceptual theory building to develop or expand } \\
\text { theoretical insights in SSCM. }\end{array}$ \\
\hline
\end{tabular}


The resulting summary of research recommendations, shown in Table 1, is instrumental to influence future SSCM research. It is evident how the suggested enquiries range across several of the SC categories and individual elements identified in Figure 1. Naturally, many of the recommended topics relate to one or multiple sustainability dimensions. In addition, overlaps with other key concerns in SSCM are apparent. For example, the development of indicators, metrics, and scorecards (Hassini et al., 2012; Winter \& Knemeyer, 2013) connects to performance management. Governance is a very dominant issue with calls for investigations into managerial components and practices (Winter \& Knemeyer, 2013) or the role of SC relationships and individuals (Carter \& Easton, 2011). Further prominent categories are those of risk management (Hassini et al., 2012; Winter \& Knemeyer, 2013) as well as regulatory compliance (Carter \& Easton, 2011).

One aim of the subsequently described Delphi study is to further extend these contributions, by identifying additional opportunities for future enquiries along with prioritisations regarding their importance. In combination with the recommendations in Table 1, a targeted, categorised, and up-todate research agenda for SSCM is developed.

\section{Delphi Study Process}

For the identification and evaluation of key themes and research requirements in SSCM, gathering subjective insights and judgments on a collective basis from individuals with diverse expertise seemed suitable. A panel study of experts supports our wider research focus and allows for assessing the current comprehension of the field (Seuring \& Müller, 2008a). Additionally, SCs are crossorganisational constructs, making the collection of empirical evidence complicated and therefore gathering expert opinion through a Delphi a viable option (Lummus, Vokurka, \& Duclos, 2005). Surveys and group discussions were also considered but a Delphi combines features of both methods. It supports a structured communication process by leveraging the total information available to the group whilst eliminating dominating opinion leaders. A Delphi also allows for the revision of previous answers and for feedback among the respondents (Linstone \& Turoff, 2002; Martino, 1983). Its iterative nature supports data richness and construct validity and yields results superior to individual responses (Okoli \& Pawlowski, 2004).

Delphi studies collate expert judgements through a series of questionnaires interspersed with controlled feedback of earlier responses (Dalkey \& Helmer, 1963; Delbecq, Van de Ven, \& Gustafson, 1975). They are effective in structuring group communication and enable a panel of experts to deal with a complex topic (Linstone \& Turoff, 2002). Delphi studies can be tailored to various problems (Schmidt, 1997), especially to achieve a group consensus regarding the importance of aspects and to develop concepts and frameworks (Okoli \& Pawlowski, 2004). In general, a Delphi is structured into distinct rounds and requires a qualified panel of experts. For the first round, researchers may include questions that solicit quantitative and qualitative data but have to ensure relevancy and validity for the study. After administration of the questionnaire, the responses need to be analysed upon which the 
next Delphi round is based. Throughout consecutive rounds the panel is asked to revise their original responses by giving consideration to the group feedback provided. This can be repeated until a consensus is reached or when sufficient information has been obtained (Delbecq et al., 1975).

Great care was taken to ensure reliability of results by following accepted guidelines. Additionally, the first Delphi round was tested by seven academics experienced in SCM and questionnaire design while the design for rounds two and three was tested by five academics respectively. The pilot testers were instructed to comment on layout and comprehensibility, the applicability of questions for the study aims, and the identification of any errors (Hasson, Keeney, \& McKenna, 2000).

This Delphi consisted of several interconnected steps as shown Figure 2. Round one is primarily formative, i.e. aimed at identification, while rounds two and three are consensus forming rounds. The decisions taken and processes conducted are outlined in this section in sequential order.

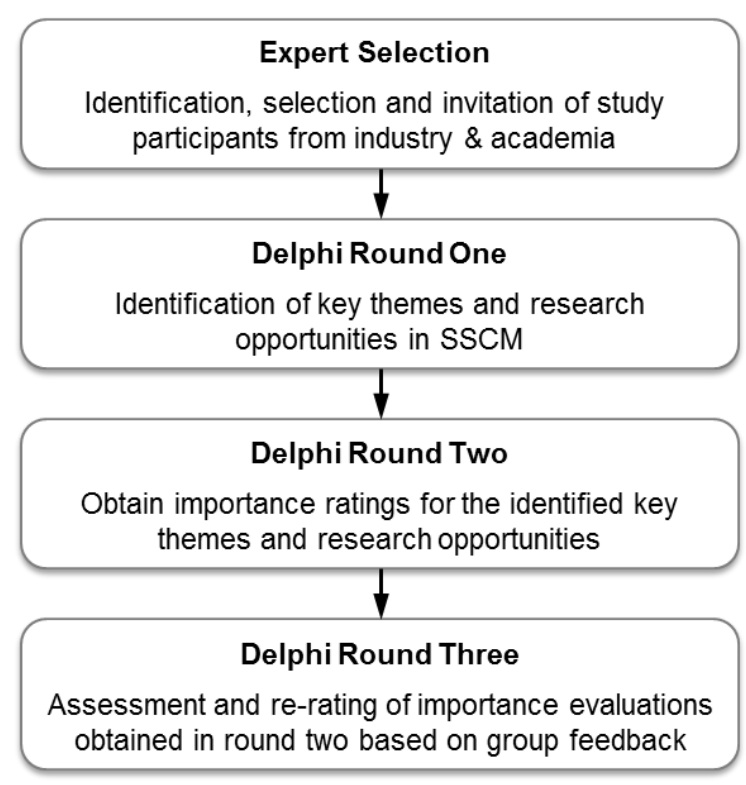

Figure 2: Delphi Study Process

\subsection{Expert Selection}

Success of a Delphi does not depend on a representative sample (Okoli \& Pawlowski, 2004) but requires informed experts that possess varied information (Rowe, Wright, \& Bolger, 1991). Scheele (2002) advises to combine experts with diverse backgrounds, e.g. affected stakeholders; domain experts; or individuals with alternative views. This Delphi was exploratory in nature and the inclusion of experts from academia and industry was advisable in order to gather a wide array of opinions. Similarly, in their Delphi study on core issues in SSCM, Seuring and Müller (2008a) selected academics, experts from industry and non-governmental organisations. The identification and selection of experts followed a structured approach as suggested by recognised guidelines (Dalkey, 1969b; Dalkey \& Helmer, 1963; Delbecq et al., 1975; Okoli \& Pawlowski, 2004). Experts were matched to objective inclusion criteria (Williams \& Webb, 1994) in order to avoid a non-representative sample (Hill \& Fowles, 1975; von der Gracht \& Darkow, 2010): 
1. Have a track record in professional and/or academic practice.

2. Have experience in SCM and/or sustainability, substantiated through:

a. employment as SCM practitioner for at least 2 years, or

b. academic employment in areas associated with SCM for at least 2 years, or

c. having published in the research areas in respected publication outlets, or

d. employment at SC stakeholders, e.g. government and NGOs, or

e. employment in sustainability related functions.

3. Demonstrate continuing professional interest in SCM and/or sustainability.

The first two criteria excluded participants that did not exhibit the knowledge required while the last criterion was included to ensure the participants' willingness for engagement and to minimise attrition. In order to only attract interested experts, this Delphi provided and adhered to expectations set at the beginning of the study (Day \& Bobeva, 2005), i.e. the study objectives, participants' responsibilities, time commitments, and knowledge pre-requisites were clearly communicated.

The size of an expert panel depends on the research objectives, the homogeneity of the experts, the need for representative pooling of judgements, the amount of information to be assessed, and also on the resources available for analysis and administration. Recommendations range from less than 15, to a maximum of 50 experts (Delbecq et al., 1975; Hsu \& Sandford, 2007; Ludwig, 1997). The experts in this Delphi can be categorised into academics and practitioners working across a variety of industries and organisation sizes as evident from Table 2 and Table 3. A total of 28 academics were approached to take part in the study who were selected based on their academic output/experience in the field and identified through university contacts. The practitioners were primarily recruited from members and associates of a SC research network. Here, an initial population of 31 individuals was contacted with managerial roles in SCM and/or sustainability. The majority of experts were from the Australasian region but both panels also comprised experts from Europe and North America.

Table 2: Organisation Types

\begin{tabular}{|l|c|c|c|}
\hline Organisation Type & Round 1 & Round 2 & Round 3 \\
\hline Agriculture & 1 & 2 & 1 \\
\hline Business Services & 3 & 2 & 2 \\
\hline Education/Academic Institution & 15 & 16 & \\
\hline Export/Import & 2 & & \\
\hline Government/Public/Defence & 3 & & \\
\hline Information and Communications Technologies & 1 & & \\
\hline Manufacturing & 1 & & 3 \\
\hline Nongovernmental Organisation & 1 & 4 & \\
\hline Transport/Storage & 7 & & $\mathbf{2 0}$ \\
\hline Wholesale Trade & 1 & $\mathbf{2 4}$ & \\
\hline Overall & $\mathbf{3 5}$ & & \\
\hline
\end{tabular}


Table 3: Organisational Headcounts

\begin{tabular}{|l|c|c|c|}
\hline Organisational Headcount & Round 1 & Round 2 & Round 3 \\
\hline $1-5$ & 2 & 3 & 2 \\
\hline $6-19$ & 1 & 0 & 0 \\
\hline $20-49$ & 1 & 0 & 0 \\
\hline $50-99$ & 0 & 2 & 4 \\
\hline $100-499$ & 6 & 1 & 1 \\
\hline $500-999$ & 5 & 4 & 13 \\
\hline Above 1000 & 20 & 14 & $\mathbf{2 0}$ \\
\hline Overall & $\mathbf{3 5}$ & $\mathbf{2 4}$ & 0 \\
\hline
\end{tabular}

All experts from the initial population were invited to participate in rounds one and two while only the experts who responded in the second round were considered for inclusion in the third round in order to ensure a rigorous rating process. Attrition effects are common in multi-step studies. In this Delphi the attrition between successive rounds, as shown in Table 4, was non-systematic and could be attributed to increasing time involvements and necessary engagement. The total number of responses remained well within the recommendations for Delphi panel sizes. Importantly, the rate of drop-outs from one rating based round (Round Two) to the next (Round Three) was reasonably low. As a result, a large panel of experts contributed to the initial list of themes and research opportunities in round one while the ratings were supported by a relatively consistent panel, i.e. the response rate in round three was $83.3 \%$. The experts were classified into academics and practitioners according to their self-indicated current place of work which resulted in a higher proportion of experts classified as academics. However, analysis of the experts' professional background indicates that many of the academics possess a substantial industry background.

Table 4: Response Rates

\begin{tabular}{|l|lr|c|c|c|c|}
\hline & \multicolumn{2}{l}{ Initial Population } & Academics & Practitioners & Total & Response Rate \\
\hline Round 1 & $\begin{array}{l}\text { Academics: } \\
\text { Practitioners: }\end{array}$ & 31 & 15 & 20 & 35 & $59.3 \%$ \\
\hline Round 2 & $\begin{array}{l}\text { Academics: } \\
\text { Practitioners: }\end{array} \quad 31$ & 16 & 8 & 24 & $40.7 \%$ \\
\hline Round 3 & $\begin{array}{l}\text { Academics: } \\
\text { Practitioners: }\end{array} \quad 8$ & 14 & 6 & 20 & $83.3 \%$ \\
\hline
\end{tabular}

\subsection{Round One}

The first round consisted of three open-ended questions. Such an approach is advisable for ill-defined research areas when pre-selected items are not an option (Day \& Bobeva, 2005; Dillman, 2007; Hasson et al., 2000; Zikmund, 2003). It allowed experts to provide their opinions as precisely as possible and supported the elicitation of unanticipated information (Engwall, 1983; Zikmund, 2003). The experts were presented with the following questions:

1. In YOUR OPINION, what are KEY Performance Indicators/Measures/Metrics of SSCs?

2. In YOUR OPINION, what are KEY Characteristics/Capabilities/Enablers of SSCs?

3. Please feel free to leave additional comments on:

- Sustainability in SCs in general.

- Other particular aspects of SSCs that require further research. 
Following a structured data collection process (Schmidt, 1997), the participants were encouraged to provide as many suggestions as possible along with descriptions and justifications. The researchers refrained from proposing a minimum number of answers as this could have discouraged respondents from exceeding that suggestion. The rationale for question 1 was that important areas or themes of SSCM would be reflected by appropriate measurements. Question 2 was primarily targeted at assessing the experts' understanding of key aspects in SSCM while question 3 captured research opportunities and additional thoughts or concerns. The experts' responses offered rich insights reaching across these primary foci. The responses were therefore analysed in combination as outlined below.

The analysis as illustrated in Figure 3 followed guidelines for general analytical procedure by Miles and Huberman (1994). The data was coded in order to maintain traceability of individual participants, date and time, and the question number (Step 1). Noise was reduced by consolidating information into 'nuggets' that referred directly to the study context, i.e. all relevant information was retained (Step 2). The resulting nuggets were firstly sorted into emerging categories for each question separately (Step 3). A subsequent cross comparison of these categories between questions (Step 4) led to the development of 46 SSCM themes and 21 research opportunities (Step 5).

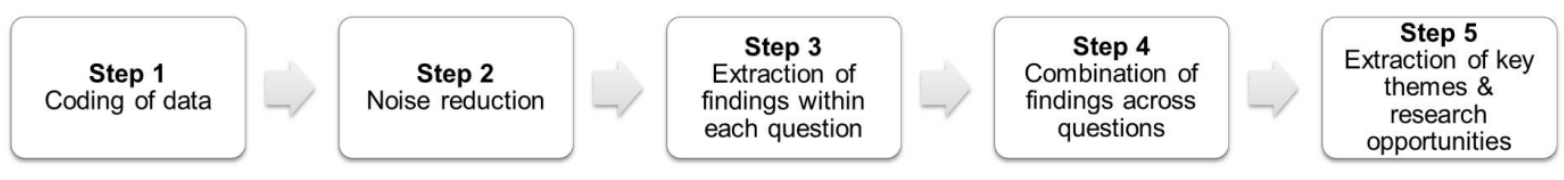

Figure 3: Round One Analysis Process

\subsection{Round Two}

The second round questionnaire required the development of suitable rating scales but their use in Delphi studies is only rarely discussed. Abstract scales can allow for relative measurements and are particularly suited for measuring values (Scheibe, Skutsch, \& Schofer, 2002). Turoff (1970) advocates the use of scales without neutral answers in order to promote a debate. However, this option should only be used if most respondents are leaning into a certain direction (Friedman \& Amoo, 1999). A neutral answer option is preferable if respondents can adopt such a position as results may otherwise become biased (Cox, 1980). Unbalanced scales also show higher stability and internal consistency (Evans \& Heath, 1995). Five-point or seven-point scales are generally preferred since smaller scales cannot transmit as much information and can stifle respondents whereas larger scales are not more accurate (Cox, 1980; Preston \& Colman, 2000). Accordingly, five-point scales were used to rate the importance of identified items (Table 5). It included a 'middle response option and also a 'nonresponse' option for rating the research opportunities.

Table 5: Importance Rating Scale with Numerical Values

\begin{tabular}{|l|c|c|c|c|c|c|}
\hline Numerical Value & $\mathbf{1}$ & $\mathbf{2}$ & $\mathbf{3}$ & $\mathbf{4}$ & $\mathbf{5}$ & $\mathbf{-}$ \\
\hline Importance Scale & Unimportant & $\begin{array}{c}\text { Of Little } \\
\text { Importance }\end{array}$ & $\begin{array}{c}\text { Moderately } \\
\text { Important }\end{array}$ & Important & $\begin{array}{c}\text { Very } \\
\text { Important }\end{array}$ & Don't know \\
\hline
\end{tabular}


The analysis, as illustrated in Figure 4, started with an assessment of potential data inconsistencies (Step 1) but no incomplete responses or errors were encountered. Numerical values were then assigned to the rating options (see Table 5) and items were sorted by their mean ratings (Step 2). The mean provided a useful measure for the central tendency of responses while the standard deviation (SD) indicated the level of dispersion. Further statistical measures facilitated an analysis of the level of consensus reached for each individual item (Step 3). These measures guaranteed objective decisions and largely avoided qualitative judgements. While universally accepted rules are not defined, it can generally be stated that enough responses within a specified range are good indicators for a consensus (Miller, 2006 in Hsu \& Sandford (2007)). Following this approach, appropriate measures were developed based on acknowledged suggestions from literature. A consensus can be considered established if $51 \%$ of responses fall within one category of a five-point scale (Loughlin \& Moore, 1979). Other authors suggest that about $80 \%$ of responses should be within two joining categories (Mitchell, 1991; Ulschak, 1983). A non-hierarchical k-means clustering procedure was also employed followed by a final qualitative assessment. The measures were used in conjunction in order to assess the level of consensus. As a result, 31 items of the 67 items rated in the second round were retained for the third round as they had not reached a sufficient level of consensus (Step 4).
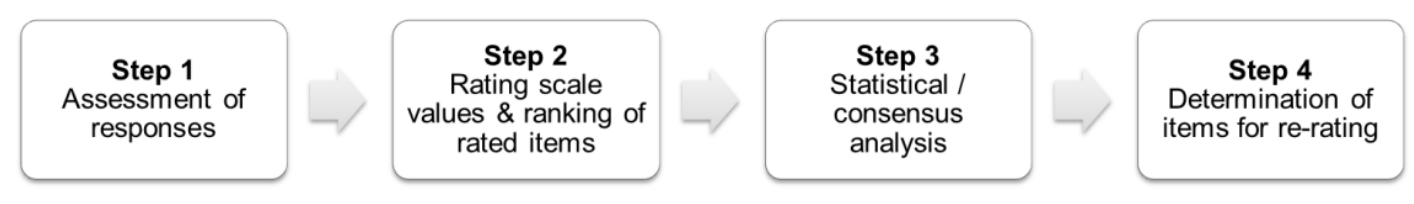

Figure 4: Round Two Analysis Process

\subsection{Round Three}

The third round design was similar to the previous round but also provided feedback on the group opinion. Mean ratings were used to convey importance ratings whereas the corresponding SD indicated the spread of responses. Any negative influences of outlying responses on mean values could be disregarded due to very few outliers (Mitchell, 1991). Qualitative feedback was not provided due to negligible extreme opinions.

The analysis process (Figure 5) was analogous to the previous round starting with an initial data assessment (Step 1) and ranking of the re-rated items (Step 2). The same analysis as in the previous round was then used to assess the levels of consensus (Step 3) and whether the study could be terminated. Expert judgments can become more valid over iterations and a Delphi should ideally continue until no further insights are gained (Rowe et al., 1991). Early termination may result in insufficient insights whereas unnecessarily long studies require more resources and cause fatigue among the panellists (Hasson et al., 2000; Schmidt, 1997) leading to distorted results (Martino, 1972; Mitchell, 1991). The literature recommends between two and four rounds (Linstone \& Turoff, 2002) with a preference for fewer rounds if sufficient levels of consensus can be reached (Dalkey, 1969a; Dodge \& Clark, 1977; Mitchell, 1991). A suitable convergence of opinions is often reached in three rounds (Ludwig, 1997; Scheibe et al., 2002; Uhl, 1971) which also offers a reasonable balance 
between resource requirements and the aims of consolidation, evaluation and refinement (Lummus et al., 2005; Okoli \& Pawlowski, 2004; Seuring \& Müller, 2008a). Since the analysis showed sufficient levels of consensus, this Delphi was terminated after three rounds (Step 4).
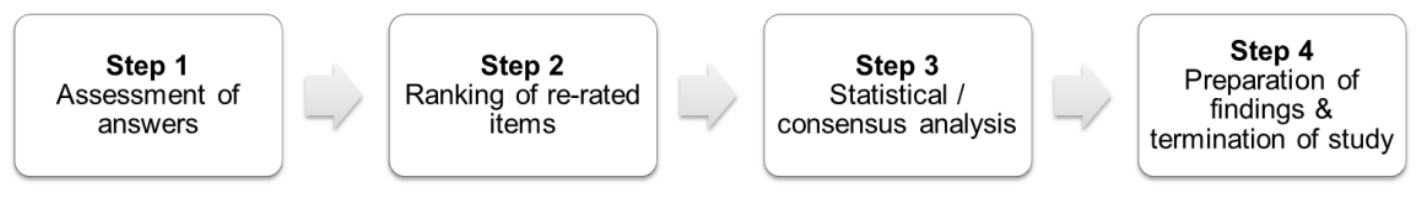

Figure 5: Round Three Analysis Process

The responses were checked for any variations depending on the experts' backgrounds. In the final Delphi round there were 6 practitioners, 9 academics, and 5 experts currently working in academia with an average industry experience of around 20 years each. The ratio of academic to practitioner viewpoints can thus be considered relatively balanced. Hence, the study findings reflect both practitioner and academic perspectives. This characteristic could also explain why significant differences between the responses of two groups were not evident.

The success of the consensus building process can be demonstrated by plotting the respondents' average deviations from the panel's mean responses in the second round against the respondents' average deviations between their second and third round ratings. Figure 6 shows how the respondents tended to adjust their third round answers by roughly the same amount as their second round ratings deviated from the average panel responses as also indicated by the $R^{2}$ values. This comparison can only be made for the 20 experts who participated in both rounds. Thus, this diagram illustrates the desired convergence towards a common group opinion. The overall consensus was significantly higher after the third round, supporting the termination of the Delphi.

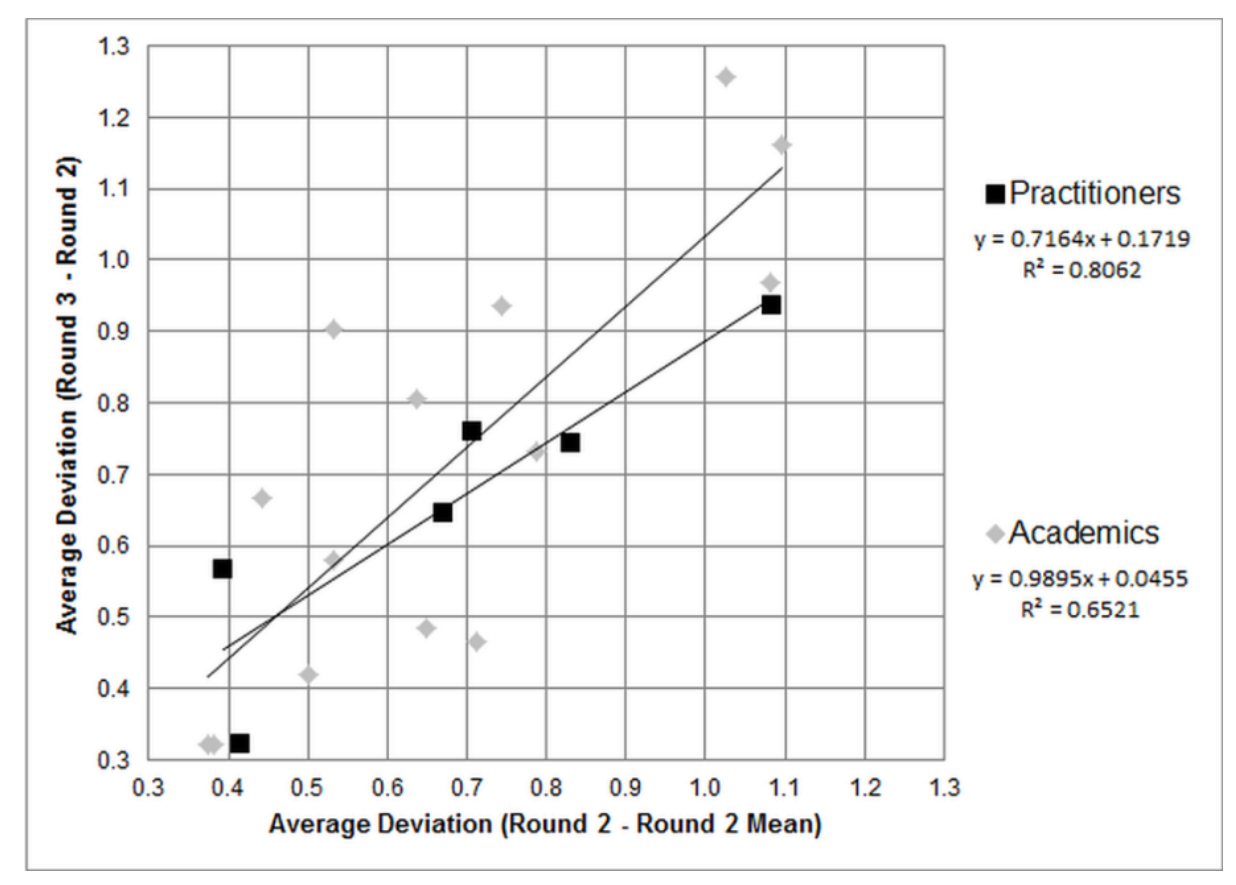

Figure 6: Consensus Building 


\section{Results and Discussion}

\subsection{SSCM Themes}

Key themes central to SSCM were identified solely through the open-ended questions in the first Delphi round. These SSCM themes were categorised as shown in Figure 7 and subsequently evaluated in terms of importance on a five-point scale in rounds 2 and 3 . As explained in the literature review, these categories are well-established in academia and practice and reflect common SC elements.

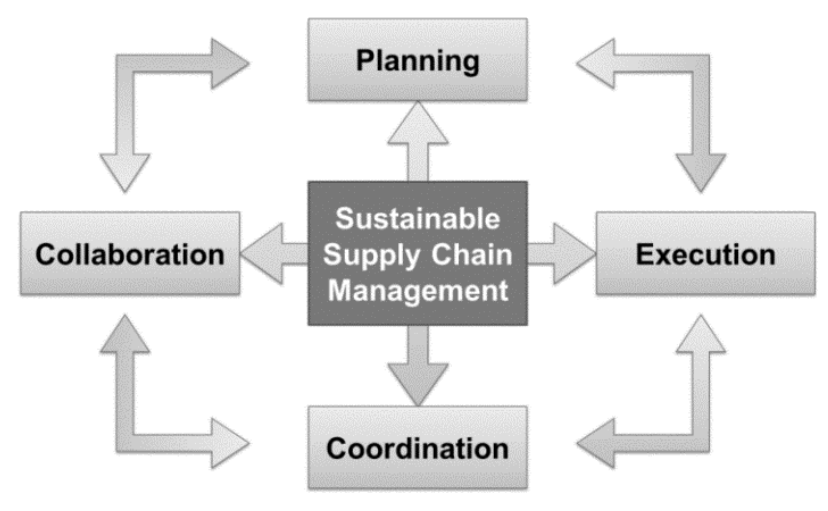

Figure 7: SSCM Theme Categories

The categorisation process can be classified as abductive reasoning, i.e. this analysis serves as a useful scenario among other possibilities. The rationale for categorising the themes is threefold. Firstly, a structure was required that was easily approachable by the expert panel during the rating exercises in rounds 2 and 3 . Secondly, the developed themes should be enfolded against existing SC theory. Thirdly, the results should be put into a context that is applicable to academia and industry. Due to these complexities, the themes were independently assessed by two researchers and the categorisation was subsequently agreed upon. Furthermore, the applicability of the themes, for the Delphi process as well as the presentation of results, was confirmed through pilot testing. It should be acknowledged that empirical data can be interpreted in multiple ways (Ketokivi \& Mantere, 2010) and hence, other categorisations might also be coherent. As became evident through the literature review, overlaps exist between these SC categories and hence, also individual themes could have been sorted differently. Acknowledging this potential shortcoming, the chosen categories adequately meet our rationale for the categorisation process.

The SSCM themes constitute a wide-ranging overview that supports theory extensions and SC practice. In combination with the importance ratings, the SSCM themes provide guidance when evaluating sustainability performance. Emphasis should be placed on tracking progress in the identified areas. The existence of elements and requirements crucial for SSCM can be assessed while the rankings allow for prioritising the development of characteristics and measures according to the importance of the themes. 


\subsubsection{Planning}

Only few, if any, SCs operate based on a truly sustainable model (Pagell \& Wu, 2009). Planning and design can facilitate a move towards SC sustainability but evidence suggests that its importance is frequently ignored (Liu et al., 2014). In support of SSCM planning a total of 14 themes were identified, with the rankings ranging from moderately important to highly important (Table 6).

Table 6: SSCM Planning Themes

\begin{tabular}{|c|c|c|c|c|c|}
\hline & SSCM Planning Themes - Importance Ranking & 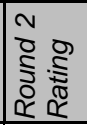 & 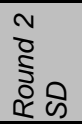 & 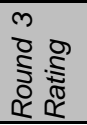 & $\begin{array}{l}m \\
0 \\
\$ \\
0 \\
\simeq \omega\end{array}$ \\
\hline 1 & $\begin{array}{l}\text { Management Structure to support SSCM, e.g. top management support, commitment to } \\
\text { SSCM }\end{array}$ & 4.71 & 0.55 & & \\
\hline 2 & $\begin{array}{l}\text { Long-Term Focus on sustainability goals, e.g. accepting sustainability as part of long-term } \\
\text { strategy }\end{array}$ & 4.46 & 0.78 & & \\
\hline 3 & Applicable SSCM Goals, i.e. sustained competitive advantage, robustness of the SC & 4.33 & 0.82 & & \\
\hline 4 & Investments in sustainability strategy/efforts, i.e. investment decisions and cost allocations & 4.04 & 0.62 & & \\
\hline 5 & Sustainability Change Management, e.g. innovations and ability to improve & 4.00 & 0.72 & & \\
\hline 6 & Incentives for SSCM, e.g. regulations, subsidies, savings, consumer demand & 3.88 & 1.03 & 3.95 & 0.76 \\
\hline 7 & Uncertainty of future sustainability requirements and related investments & 3.50 & 0.93 & 3.90 & 0.64 \\
\hline 8 & $\begin{array}{l}\text { Strategic Frameworks/Models/Methods, e.g. to support discussion and investigation of } \\
\text { alternatives }\end{array}$ & 3.92 & 0.78 & 3.85 & 0.88 \\
\hline 9 & Management of Modal Choices, e.g. choosing appropriate transportation modes & 3.83 & 0.64 & & \\
\hline 10 & Attention to regionally specific issues, e.g. food miles, restructuring needs, SC length & 3.71 & 1.08 & 3.80 & 0.89 \\
\hline 11 & Location Choices, e.g. locations of warehouses and related area usage & 3.71 & 0.75 & & \\
\hline 12 & Renewability of Resources, e.g. usage of (non-)renewable materials and energy & 3.63 & 0.77 & & \\
\hline 13 & $\begin{array}{l}\text { Research in sustainability and SCs, e.g. into effects of sustainability efforts, missing } \\
\text { sustainability models/frameworks/roadmaps }\end{array}$ & 3.54 & 0.72 & & \\
\hline 14 & Location Type, e.g. open air, refrigerated, hazardous storage & 3.50 & 0.88 & 3.50 & 0.83 \\
\hline
\end{tabular}

SC decision makers concerned with operational, strategic, and design aspects are in a crucial position to start sustainability initiatives as their actions can impact directly on the quality of life, safety, health, and public welfare (Sarkis, 1998). This importance is reflected by the identified themes, i.e. the need for supportive management structures (Rank 1) and monetary investments into SSCM (Rank 4). Only with sufficient support and commitment from managerial decision makers can planning decisions be realised. The importance of internal management support for the successful implementation of sustainable SC practices has previously been emphasised in literature (Zhu, Sarkis, Cordeiro, \& Lai, 2008). A long term strategic focus (Rank 2) and applicable goals to work towards (Rank 3), on transitional and final levels, support the idea of improving the sustainability of a SC on a continuous basis whilst alleviating opposition to change (Munro, 1995; Pagell \& Wu, 2009).

Many leading organisations are addressing sustainability challenges and are re-designing their internal and SC operations. Disconnected ad-hoc sustainability initiatives should be avoided in this context and SCs should instead focus on a holistic long-term strategy and plan their operations around SC efforts (Carter \& Rogers, 2008). Actual sustainable SC design ranges from cautious followers to proactive strategies. Two main SSCM strategies have been identified in literature, i.e. a risk-oriented focus based on supplier evaluations and an opportunity-oriented strategy focussed on active SC and supplier developments (Harms, Hansen, \& Schaltegger, 2012; Seuring \& Müller, 2008b). Risk-oriented strategies are generally more prevalent which may be influenced by a lack of knowledge regarding incentives for SSCM (Rank 6). In support of SSCM design, structured sustainability change management (Rank 5 ) is suggested by the experts. Similarly strategically 
utilizing SSCM frameworks and models (Rank 8) is seen as important which may be further supported by research into SSCM (Rank 13). Such targeted research efforts may furthermore be beneficial to decrease the many uncertainties surrounding SSCM and sustainability efforts in general (Rank 7).

Planning decisions in SCM can have positive as well as negative sustainability impacts through e.g. supplier selection, modal choices and vehicle routing, or location and packaging options (Carter \& Easton, 2011; Murphy \& Poist, 2003). Related planning themes seen as particularly important for SSCM include the management of modal choices (Rank 9) and the mindful selection of locations (Rank 11 and 14) and resources (Rank 12) for SC operations. Interestingly, the experts also emphasised the importance of regional SC issues (Rank 10) which require targeted efforts and knowledge of local conditions and regulations. The importance of such planning decisions is underlined by the finding that proactive management, e.g. anticipating regulatory changes, is often associated with competitive advantages (de Brito, Carbone, \& Blanquart, 2008; Prokesch, 2010) including e.g. licensing royalties and the development of unique capabilities (Kleindorfer, Singhal, \& Van Wassenhove, 2005).

\subsubsection{Execution}

Dynamics in increasingly global SCs force the integration of sustainability principles into strategic priorities and daily operations, i.e. SC execution (Carter \& Rogers, 2008; Jayaraman et al., 2007; McIntyre, 2007; Seuring \& Müller, 2008b). The 15 identified SSCM execution themes are directed towards operational activities and were rated moderately to highly important, showing a considerable spread in the ranking (Table 7).

Table 7: SSCM Execution Themes

\begin{tabular}{|c|c|c|c|c|c|}
\hline & SSCM Execution Themes - Importance Ranking & 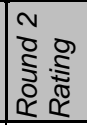 & \begin{tabular}{l} 
v \\
0 \\
5 \\
\multirow{2}{5}{ ต }
\end{tabular} & 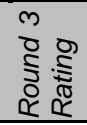 & 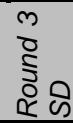 \\
\hline 1 & $\begin{array}{l}\text { Availability of Information and Information technology, e.g. for forecasting, process } \\
\text { variability, emissions, cost allocation, etc. }\end{array}$ & 4.50 & 0.78 & & \\
\hline 2 & Operational Accuracy, e.g. timeliness, quality, correctness, zero damage, etc. & 4.08 & 0.78 & 4.45 & 0.83 \\
\hline 3 & Customer Satisfaction, i.e. meeting expectations of internal/external customers & 4.38 & 0.71 & & \\
\hline 4 & Employee Measures, e.g. satisfaction, training support, working conditions, remuneration & 4.00 & 0.72 & 4.25 & 0.72 \\
\hline 5 & Utilisation/Efficiency in Transportation, e.g. utilisation of vehicles, total distances travelled & 4.13 & 0.68 & & \\
\hline 6 & Utilisation/Efficiency in Warehousing, e.g. stock turns, energy/land usage & 4.08 & 0.58 & & \\
\hline 7 & $\begin{array}{l}\text { Measurement and Performance Tracking, e.g. access to and knowledge of effective tools } \\
\text { and technology }\end{array}$ & 4.04 & 0.75 & & \\
\hline 8 & Health and Safety Measures, e.g. accident rates and preventive measures & 3.88 & 1.08 & 3.95 & 0.76 \\
\hline 9 & Waste and Recycling Management & 3.75 & 0.90 & 3.85 & 0.75 \\
\hline 10 & Documentation, e.g. solutions for effective traceability & 3.83 & 0.70 & & \\
\hline 11 & Footprints of SC impact, e.g. tracking environmental footprints & 3.75 & 0.90 & 3.80 & 0.95 \\
\hline 12 & Resource Usage, e.g. energy or material consumption & 3.75 & 0.68 & & \\
\hline 13 & Maintenance of Equipment, e.g. vehicles, machinery, buildings, etc. & 3.50 & 0.83 & 3.55 & 0.83 \\
\hline 14 & Emission Levels and Types, e.g. greenhouse gas emissions or waste water & 3.54 & 0.78 & & \\
\hline 15 & $\begin{array}{l}\text { Consulting, e.g. outside help to support sustainability transformation like consulting firms, } \\
\text { specialised freight companies, NGOs }\end{array}$ & 3.21 & 0.72 & & \\
\hline
\end{tabular}

According to the expert panel, the most important execution themes are the availability of information and suitable IT (Rank 1) as well as maintaining operational accuracy (Rank 2). Closely related to these goals is the need for measurement and performance tracking (Rank 7). These themes 
correspond to the need for economic success in order to support SSCM (Carter \& Rogers, 2008), which depends largely on customer satisfaction (Rank 3 ) and efficient resource usage (Rank 12).

Logistics and transportation activities account for an estimated $5.5 \%$ of global carbon emissions (World Economic Forum, 2009) and efficient execution can significantly influence a firm's carbon footprint. However, the impacts and importance of logistics for SSCM are not well understood (Dey et al., 2011). Transportation related SC decisions are traditionally based on cheap transport, often neglecting energy efficiencies (Halldórsson \& Kovács, 2010). Several of the execution themes also refer to the need for efficiency in transportation (Rank 5) and warehousing (Rank 6). Maintaining efficiencies also demands meticulous maintenance of one's equipment (Rank 13) and tracking of emissions (Rank 14). The importance of these themes is underlined by energy costs, regulations and $\mathrm{CO}_{2}$ penalties which urgently demand sustainable approaches (Dey et al., 2011). High importance was also placed on social aspects such as the support and well-being of SC employees supporting the value of social sustainability and the influence of employees on SC performance (Rank 4 and 8). Related literature points out that the equitable optimisation of all sustainability dimensions in a logistics system proves challenging and especially the social dimension is not well understood (Ramos, Gomes, \& Barbosa-Póvoa, 2014).

Attempts have been made to operationalize sustainability through structured measurement and reporting practices (Elkington, 1998; Global Reporting Initiative, 2011). Most corporate sustainability approaches are recent developments, e.g. ISO 14001, the United Nations Global Compact, or the Global Reporting Initiative (Birkin, Polesie, \& Lewis, 2009). The Delphi findings point to several aspects in this regard including the need for waste and recycling management (Rank 9), accurate documentation (Rank 10), and footprinting of SC impacts (Rank 11). These themes may help to overcome common criticisms of structured management approached such as a lack of guidance (Norman \& MacDonald, 2004) or the potential to support hypocrisy (Blengini \& Shields, 2010; Robinson, 2004). The lowest rating was assigned to the need for consulting (Rank 15), potentially due to the fact that the influence of consulting firms on SSCM execution are specific to each SC.

\subsubsection{Coordination}

Managers are frequently overwhelmed by the coordination of intricate connections and interdependencies in a SC (Lambert \& Cooper, 2000). Additionally, sustainability principles are often only applied internally or with selected partners and do not extend to all SC tiers. (KPMG, 2011; Turner \& Houston, 2009). The identified themes relate to such coordination requirements (Table 8 Error! Reference source not found.).

Common coordination mechanisms include information sharing and technology (Akkermans \& Vos, 2003; Arshinder \& Deshmukh, 2008), incentive systems (Li, Chung, Goldsby, \& Holsapple, 2008), contracts (Arshinder \& Deshmukh, 2008; Sarmah, Acharya, \& Goyal, 2006; Selviaridis \& Spring, 2010), joint decision making (Arshinder \& Deshmukh, 2008), and reputation effects (Ching, Holsapple, \& Whinston, 1996). Several of the SSCM coordination themes identified relate to such mechanisms. Access to information across the SC (Rank 3 ) is highly relevant as also previously identified by Zhu et 
al. (2008). Additionally, incentives for people management are pointed out along with the need for SSCM education and training (Rank 7). The Delphi experts suggest that SSCM also benefits from contributing to the wellbeing of the local community/society (Rank 8) and to a lesser extent by empowering sub-groups (Rank 11). These aspects may also be especially relevant for creating a positive reputation.

Table 8: SSCM Coordination Themes

\begin{tabular}{|c|c|c|c|c|c|}
\hline & SSCM Coordination Themes - Importance Ranking & 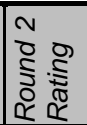 & 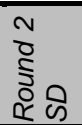 & 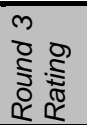 & 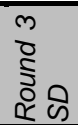 \\
\hline 1 & Alignment, e.g. synchronisation of SC elements, initiatives, goals & 4.46 & 0.51 & & \\
\hline 2 & SC Costs, e.g. cost allocations for all operations and reductions over time & 4.33 & 0.64 & & \\
\hline 3 & Accessibility of items/information, e.g. availability of inventory, tracking options & 4.21 & 0.72 & & \\
\hline 4 & SC Profits, e.g. revenue per unit of output, productivity of each operation & 4.17 & 0.56 & & \\
\hline 5 & Compliance Measures/Regulations, e.g. government or industry regulations & 3.96 & 0.91 & 4.10 & 0.64 \\
\hline 6 & $\begin{array}{l}\text { Targets and Benchmarking, e.g. investment/reduction targets and benchmarking with } \\
\text { established measures }\end{array}$ & 4.00 & 0.93 & 4.10 & 0.45 \\
\hline 7 & People Management, e.g. incentives, training, education & 3.96 & 0.75 & 4.05 & 0.60 \\
\hline 8 & $\begin{array}{l}\text { Contributions/Impacts on Local Community/Society, e.g. benefits provided, dependence on } \\
\text { SC, noise levels, use of land }\end{array}$ & 3.75 & 0.94 & 3.90 & 0.79 \\
\hline 9 & Trade-off Management, i.e. provide a balance between sustainability goals & 3.92 & 0.97 & 3.80 & 0.52 \\
\hline 10 & Cost Allocations for unaccounted SC impacts, e.g. emissions and environmental impacts & 3.67 & 0.92 & 3.70 & 0.73 \\
\hline 11 & Empowerment, e.g. education/training and support for sub-groups (women, handicapped) & 3.33 & 0.92 & 3.30 & 0.57 \\
\hline
\end{tabular}

Among the 11 themes identified, particular importance was assigned to SC alignment and accessibility as well as economic concerns. The importance of alignment between SC members regarding e.g. information exchange, responsibilities, goals and incentives has been much discussed in literature especially in light of SC agility and adaptability (Lee, 2004; Narayanan \& Raman, 2004). Hence, a close link of alignment and coordination in SSCM (Rank 1) is well justified. Other prevalent themes relate to establishing goals and targets along with measuring and tracking SC performance (Rank 5 and 6). This corresponds to literature which suggests that the introduction of coordinating mechanisms such as sustainability policies and goals is advantageous for SSCM (Seuring \& Müller, 2008b). It has furthermore been suggested that bottom-up SSCM initiatives may need incentives through top-down governmental support especially if their implementation leads to economic disadvantages (Genovese, Acquaye, Figueroa, \& Koh). Coordinating the adoption of SSCM would obviously be supported by economic profitability and accordingly the Delphi experts place emphasis on issues such as cost allocations and reductions across the SC (Rank 2), tracking of profits (Rank 4), and cost accounting of sustainability related SC impacts (Rank 10). Apart from this economic focus, SSCM coordination depends on trade-off management for a balanced sustainability approach (Rank 9).

\subsubsection{Collaboration}

The category of SSCM collaboration is closely related to coordination but reflects the shift in academic discourse towards SC collaboration and the importance of a cross-organisational focus. Extending coordination across organisational boundaries, i.e. SC collaboration, is a challenging and complex endeavour (Arshinder \& Deshmukh, 2008). The six identified themes offer guidance in this regard and appear applicable to most SC configurations (Table 9). The findings emphasise the 
importance of developing SC visibility, trust, a common strategy and vision, effective change management processes, as well as active relationship management. These findings partially mirror inter-organisational resources identified as success factors for SSCM (Gold et al., 2010; Zhu et al., 2008).

Table 9: SSCM Collaboration Themes

\begin{tabular}{|c|c|c|c|c|c|}
\hline & SSCM Collaboration Themes - Importance Ranking & 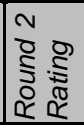 & 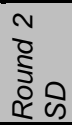 & 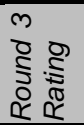 & 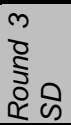 \\
\hline 1 & Collaboration, e.g. information sharing, regular updates, joint ventures & 4.33 & 0.92 & & \\
\hline 2 & Integration of processes, i.e. full visibility from 'cradle to grave' & 4.33 & 0.70 & & \\
\hline 3 & $\begin{array}{l}\text { Attitude towards SSCM, i.e. awareness of its values and aims, a mentality to embrace } \\
\text { change }\end{array}$ & 4.29 & 0.81 & & \\
\hline 4 & $\begin{array}{l}\text { External Relationship Management, e.g. measuring service levels, sustainability } \\
\text { performance for external stakeholders }\end{array}$ & 4.25 & 0.68 & & \\
\hline 5 & Internal Relationship Management, e.g. measuring strategic alignment within SC & 4.21 & 0.59 & & \\
\hline
\end{tabular}

Several interconnected factors can act as barriers for SSCM and for establishing a collaborative SC environment. These include increased coordination efforts and complexity, potentially higher costs and initial investments, and insufficient or missing communication (Seuring \& Müller, 2008b). The SSCM collaboration themes relate to these issues. Insufficient communication may be counteracted by practices for information sharing and regular updates between SC partners (Rank 1). Problems associated with increased complexities and initial investments could be addressed by establishing a shared vision (Rank 6). This should be coupled with actively increasing the awareness of SSCM aims and by building a mentality to embrace associated changes (Rank 3). Placing emphasis on these aspects and in turn overcoming the barriers to SC collaboration holds the potential to improve sustainability performance for the SC overall and its individual members (Zhu \& Sarkis, 2006).

Facilitating factors include the development of a culture that embraces sustainability values and follows an integrated sustainable SC strategy for full SC visibility (Rank 2). In combination this has been found to support the alignment of initiatives with strategic priorities and reduce sustainability related risks (Carter \& Rogers, 2008). Rank 4 and 5 finally point towards the need for active internal and external relationship management based on collaborative performance assessments. Close internal SC relationships have been associated with waste elimination and the reduction, prevention and control of pollution (P. Bansal \& McKnight, 2009). External stakeholders include governments, opinion leaders, consumers, investors, business partners and competitors. They assert sustainability pressure on SCs through legal demands, regulations, and by shaping public opinion (Esty \& Winston, 2006; Seuring \& Müller, 2008b) making external relationship management instrumental to SSCM.

\subsection{Research Opportunities}

The experts were asked to propose research opportunities in the first round of the Delphi and were also given the option to provide additional ideas during the subsequent rounds. In total 21 distinct research opportunities were extracted from the experts' responses and evaluated in terms of importance as shown in Table 10. 
Table 10: SSCM Research Opportunities

\begin{tabular}{|c|c|c|c|c|c|}
\hline & SSCM Research Opportunities - Importance Ranking & 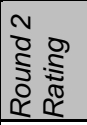 & 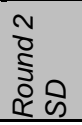 & 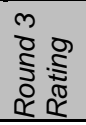 & 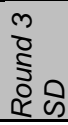 \\
\hline 1 & Actual costs of supply chain operations, e.g. unaccounted environmental and social impacts & 4.58 & 0.58 & & \\
\hline 2 & Future of supply chains, e.g. long-term outlook and restructuring needs & 4.48 & 0.59 & & \\
\hline 3 & Investments into sustainability and their justifications & 4.38 & 0.71 & & \\
\hline 4 & Claims of sustainability and actual impacts of supply chains & 4.13 & 0.85 & 4.30 & 0.86 \\
\hline 5 & Impacts on society, i.e. positive/negative effects of supply chains & 4.08 & 0.88 & 4.30 & 0.57 \\
\hline 6 & Linkages of supply chains with environmental and social systems & 4.09 & 0.85 & 4.30 & 0.57 \\
\hline 7 & Awareness of positive impacts of sustainable supply chains & 4.29 & 0.75 & & \\
\hline 8 & Implementation hurdles of sustainability initiatives, e.g. time and cost requirements & 4.29 & 0.69 & & \\
\hline 9 & $\begin{array}{l}\text { Impact of competitive forces on sustainability, e.g. sustainability efforts prevented due to cost } \\
\text { pressures }\end{array}$ & 4.27 & 0.70 & & \\
\hline 10 & Energy availability, e.g. peak oil and dependence on petrochemicals of supply chains & 4.04 & 0.81 & 4.25 & 0.79 \\
\hline 11 & Future trends and developments in supply chains & 3.92 & 0.88 & 4.25 & 0.55 \\
\hline 12 & $\begin{array}{l}\text { Long-term effect of sustainability movement in case of long supply chains and resulting } \\
\text { special requirements }\end{array}$ & 4.25 & 0.68 & & \\
\hline 13 & Long-term SSCM results, i.e. potentials and resulting benefits & 4.17 & 0.72 & 4.25 & 0.79 \\
\hline 14 & Transportation modes, e.g. which mode works best for each commodity & 3.96 & 0.82 & 4.10 & 0.55 \\
\hline 15 & Service Profit Chain and its relevance for logistics/supply chain & 3.86 & 0.89 & 4.05 & 0.62 \\
\hline 16 & Cost allocations, e.g. for sustainability efforts and unaccounted supply chain impacts & 4.04 & 0.69 & & \\
\hline 17 & $\begin{array}{l}\text { Missing theory development to guide practice, e.g. lack of strategic models and applicable } \\
\text { frameworks }\end{array}$ & 3.96 & 0.88 & 3.90 & 0.79 \\
\hline 18 & Relation of food miles and sustainability impacts & 3.82 & 0.91 & 3.90 & 0.79 \\
\hline 19 & Employee satisfaction and societal welfare & 3.88 & 0.85 & 3.75 & 0.79 \\
\hline 20 & $\begin{array}{l}\text { Effects of overemphasis of certain aspects at the detriment to others, e.g. focusing solely on } \\
\text { green-house gas emissions }\end{array}$ & 3.83 & 0.96 & 3.75 & 0.85 \\
\hline 21 & $\mathrm{CO}_{2}$ emissions and carbon footprints & 3.74 & 0.86 & 3.70 & 0.92 \\
\hline
\end{tabular}

It is evident that the suggestions differ thematically and therefore with regard to the appropriateness of research approaches and units of analysis. Since such thematic analysis is subject to interpretation and multiple perspectives (Ketokivi \& Mantere, 2010), it is useful to enfold the research opportunities against recognised structures. In concordance with the recommendations from literature (Table 1), connections to the concepts of GRC (governance, risk, and compliance) are also apparent in Table 10. Despite the ubiquitous usage of the term GRC in the business world, it remains difficult to accurately define it. This can be attributed to the lack of academic definitions on one side while many companies use the term to describe their specific understanding of it (Racz, Weippl, \& Seufert, 2010). Racz et al (2010) conclude that while "research exists on the ' $G$ ', the ' $R$ ', and the 'C' as separate topics, the potential integration moves under the radar of scientific research." While an exact definitional construct of GRC remains to be explored, a connection to sustainability can be drawn. Elkington (2006) describes complex cross-connects between corporate governance and responsibility, business ethics in value chains, and sustainable development. Following this line of thought, we organised the research opportunities according to the top level categories as shown in Figure 8. Looking at success factors in SSCM in particular (Wittstruck \& Teuteberg, 2011), it becomes apparent that the categorisation put forward here aligns well with existing academic literature. This view is further supported through leading practical approaches in the field (see e.g. Menzies et al., 2007; SAP AG, 2009). 


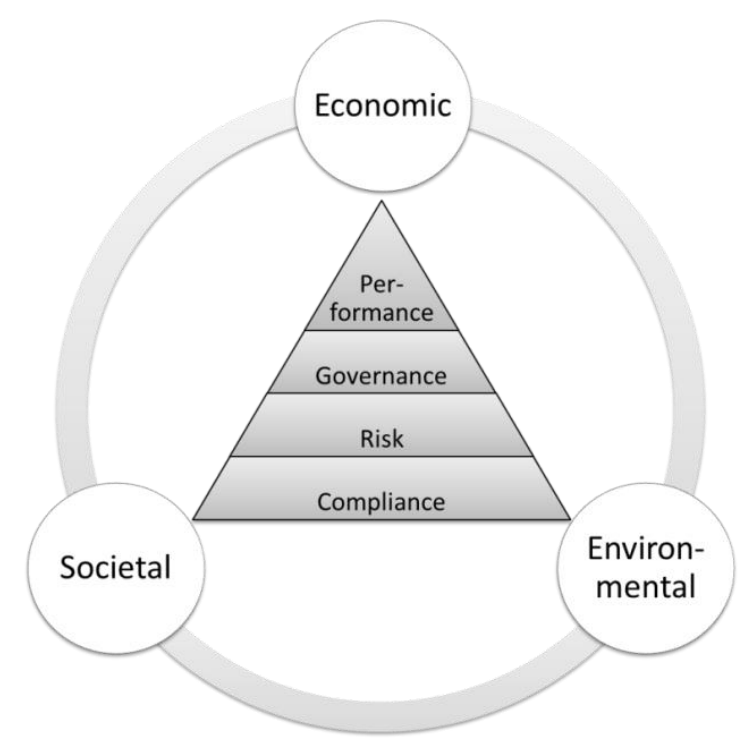

Figure 8: Research Opportunities: Structural Overview

A structural view illustrates the emergence of the following categories of research opportunities:

- Sustainability Dimensions/Characteristics (Economic, Environmental and Societal)

- Management Dimensions/Enablers (Governance, Risk, and Compliance) and

- Performance Management

Figure 8 also supports a process oriented view suggesting that GRC management can enable sustainable economic, environmental, and societal performance. Furthermore a holistic performance management approach is required on all these categories for achieving a sustainable SC. A reverse relationship can be assumed, i.e. that sustainability characteristics in effect also strengthen the management enablers.

A re-examination of the literature synthesis (Table 1) revealed that these seven categories are also present in SSCM literature with an especially prominent focus on governance and performance management. We use Tables 11-17 to synthesise the literature with the Delphi study findings. These tables not only identify the main categories that the research recommendations relate to (black dots) but also identify other related categories (grey dots) as most research opportunities overlap with multiple categories. Researchers should use these overlaps to structure their own research endeavours. In the following sub-sections we explore each of the seven categories individually. This categorisation supports the discussion of the research opportunities alongside related literature and the proposal of directions to guide such enquiries.

\subsubsection{Sustainability Dimensions}

Preliminary frameworks integrating all sustainability dimensions can be found (see e.g. Carter \& Rogers, 2008; Seuring \& Müller, 2008b; Svensson, 2007), but available research largely fails to outline how to practically integrate social and environmental considerations in SCs and clearly address the multi-objective nature of sustainable development (Eskandarpour, Dejax, Miemczyk, \& 
Péton, 2015; Pagell \& Wu, 2009). Hence, there are fundamental challenges in SSCM that are yet to be addressed. The highest ranking research opportunity calls for the investigation of unaccounted environmental and social SC impacts and the allocation of actual economic values (Table 11). Literature synthesis and the Delphi study are in concordance when it comes to studying the economic impacts of sustainability in supply chains. Several other opportunities are closely related, i.e. the fourth highest ranking opportunity calls for the investigation of sustainability claims versus actual SC impacts and also research into cost allocations of sustainability efforts and SC impacts is suggested (Rank 16). Interestingly, the previously published research recommendations (Table 1) do not directly relate to these important aspects. A thorough investigation into this particular area could be accomplished through case studies of representative SCs aimed at assessing SC structures, intended and unintended impacts, and cost accounting procedures. Companies have already made advancements in this area, e.g. novel approaches that summarise environmental impacts across the SC and convert these into an environmental profit and loss account (PwC, 2011).

Table 11: Economic Sustainability Research Opportunities

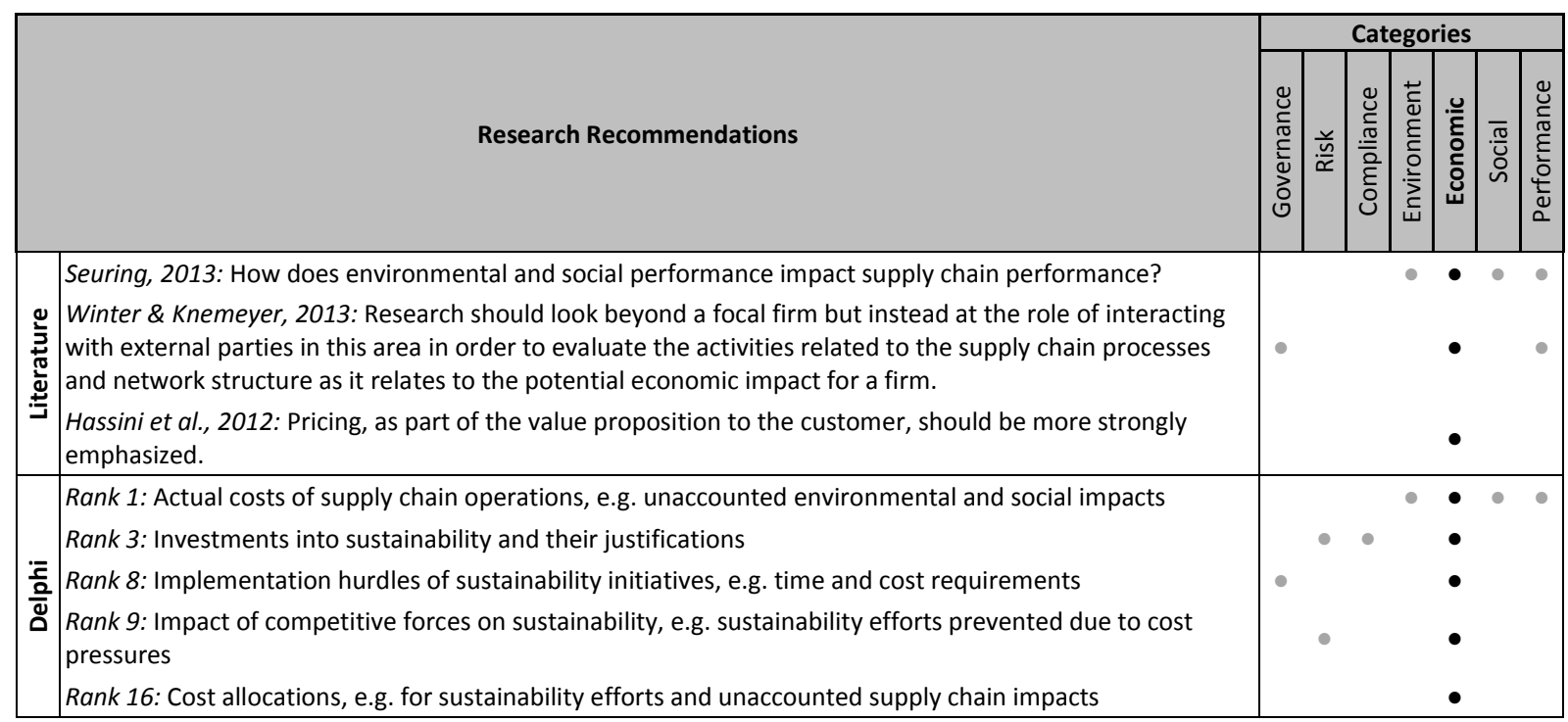

There was sparse literature that included environmental sustainability as the key focus; however the Delphi study came up with the issue of food miles (Rank 18) and its impact on sustainability (Table 12). This particular aspect has been partially addressed in specific regional contexts by Weber and Matthews (2008) and Saunders et al (2006).

Table 12: Environmental Sustainability Research Opportunities

\begin{tabular}{|c|c|c|c|c|c|c|c|c|}
\hline \multirow{2}{*}{\multicolumn{2}{|c|}{ Research Recommendation }} & \multicolumn{7}{|c|}{ Categories } \\
\hline & & 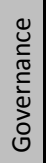 & $\frac{\breve{m}}{\underline{\underline{M}}}$ & 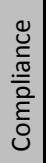 & 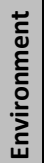 & 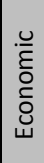 & $\begin{array}{l}\overline{\frac{\pi}{4}} \\
\text { 으 }\end{array}$ & 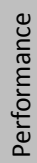 \\
\hline 츰 & Rank 18: Relation of food miles and sustainability impacts & & - & & $\bullet$ & $\bullet$ & $\bullet$ & $\bullet$ \\
\hline
\end{tabular}


Literature synthesis and the Delphi study are complementary in identifying opportunities for future research on societal sustainability (Table 13). There is a need to investigate SC impacts on society (Rank 5) as well as the effects of employee satisfaction and societal welfare on SC outcomes (Rank 19). A lack of insights on the social dimension of SSCM is frequently bemoaned in literature ( $P$. Bansal \& McKnight, 2009; Eskandarpour et al., 2015; Gold et al., 2010; Kleindorfer et al., 2005; Pagell $\& W u, 2009$ ). Seuring (2013) suggests studying and modelling the interrelation of the sustainability dimensions to support the integration of social considerations. Studying the relationship between social and economic performance is recommended. This could include an assessment of the dependencies between SSCM and employee motivation and the influence of internal stakeholders (Carter \& Easton, 2011).

Table 13: Societal Sustainability Research Opportunities

\begin{tabular}{|c|c|c|c|c|c|c|c|c|}
\hline & \multirow[b]{2}{*}{ Research Recommendations } & \multicolumn{7}{|c|}{ Categories } \\
\hline & & 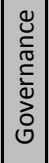 & $\frac{\ddot{n}}{\sim}$ & 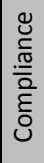 & 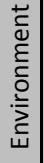 & 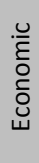 & $\begin{array}{l}\bar{\pi} \\
\text { ¿ } \\
\text { n }\end{array}$ & 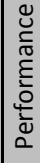 \\
\hline 竞 & $\begin{array}{l}\text { Seuring, 2013: How can the social dimension be integrated into respective models? } \\
\text { Carter \& Easton, 2011: Examine supply chain management employees as internal stakeholders, and how } \\
\text { employee attitudes and commitment to organizations might differ based on differing levels of SSCM. }\end{array}$ & & & & & & $\bullet$ & \\
\hline 흐음 & $\begin{array}{l}\text { Rank 5: Impacts on society, i.e. positive/negative effects of supply chains } \\
\text { Rank 19: Employee satisfaction and societal welfare }\end{array}$ & & $\bullet$ & & $\bullet$ & $\bullet$ & & $\bullet$ \\
\hline
\end{tabular}

\subsubsection{Performance Management}

The literature synthesis and the Delphi are in concordance and complementary in the identification of research opportunities in performance management (Table 14). Financial justifications for SSCM are required (Carter \& Easton, 2011; Winter \& Knemeyer, 2013) as reflected by the third highest ranking opportunity. Similarly, it is important to study the long term benefits of SSCM (Rank 13). These enquiries rely on certain prerequisites in order to assess the costs of SC operations on all three sustainability dimensions. Such prerequisites include methods to facilitate SC-wide performance measurements as well as a high degree of visibility, information exchange, and collaboration. In this context, Winter \& Knemeyer (2013) point to the need for estimation tools and techniques. This indicates an order of precedence, i.e. certain research outcomes are needed to support other opportunities. Supportive performance assessments extend from the development of appropriate metrics and scorecards (Hassini et al., 2012; Winter \& Knemeyer, 2013) to composite indicators and integration with existing theory (Hassini et al., 2012; Seuring, 2013). While many companies publish sustainability reports including SC measures, such efforts are often uncoordinated and incomplete due to missing standards (KPMG, 2011) and SC visibility (Awaysheh \& Klassen, 2010). Performance measurements in SCM are commonly criticised for the lack of a balanced approach taking into account strategic orientations, non-financial performance, and systems interactions. Some research 
has started to address these shortcomings in the context of SSCM (Cetinkaya, 2011; Reefke \& Trocchi, 2013) but validation through practical application is required.

Table 14: Performance Management Research Opportunities

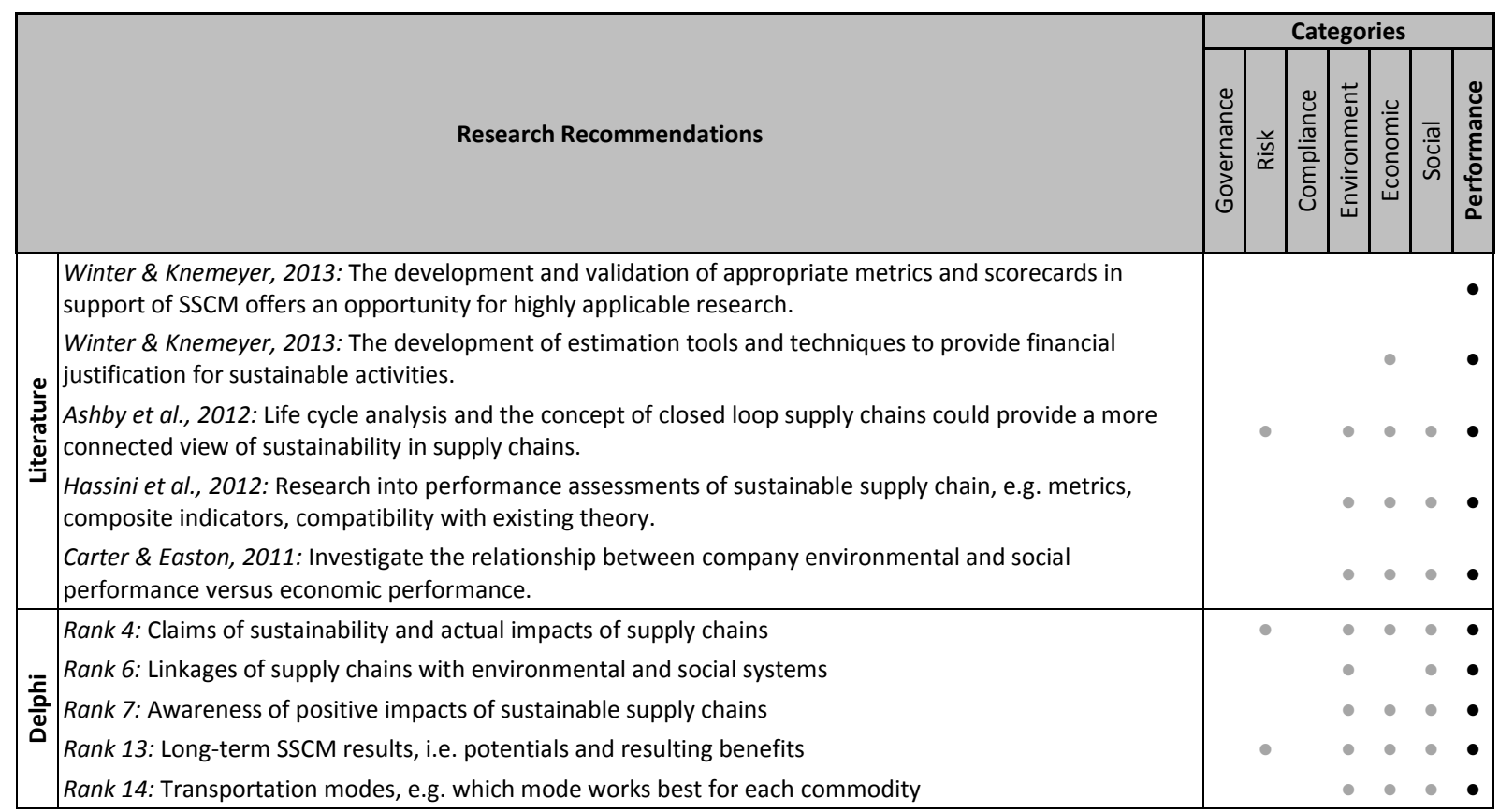

\subsubsection{Governance}

The literature synthesis along with results of the Delphi study showed a preponderance of emphasis on governance related aspects. Almost two-thirds of the literature recommendations have a primary focus on governance (Table 15). The Delphi findings also included some recommendations but not to the same level of strength or emphasis. Together the results were in concordance in many areas, but most importantly on the need for policies, structures, prescriptions and practical artefacts to guide the implementation of sustainable SCs. These are discussed in the following paragraphs.

The Delphi experts recognised that SSCM research is still in its infancy since sustainability principles have not been widely implemented in SCs yet, largely due to a prevailing focus on short term financial goals. A need for more research into policy frameworks was pointed out, e.g. determining incentives that can move SCs into a more sustainable direction. As illustrated in literature, aligning incentives in a SC can have a significant impact when trying to build common characteristics and steer SC developments (Narayanan \& Raman, 2004). Especially interesting is the notion that competitive forces could enable this transition if supported by appropriate policies. Research into revenue implications of SSCM was suggested which should consider necessary time investments and the state of sustainability development as determining factors. Investigations of cost and accounting structures of modern corporations and potential incompatibilities with SSCM were also seen as crucial. Specific issues to be assessed include possibilities for cost accounting of SC impacts, approaches to equitably share SC risks and benefits, and methods to improve the alignment of incentives and payment terms with sustainability goals. SC structures and practices undoubtedly differ 
between e.g. manufacturing and service oriented industries and the applicability of sustainability activities and SSCM theory should be studied accordingly. Carter \& Easton (2011) emphasise to study sustainability characteristics in service SCs while the Delphi experts also point to understanding the dynamics of the service profit chain (Rank 15).

Table 15: Governance Research Opportunities

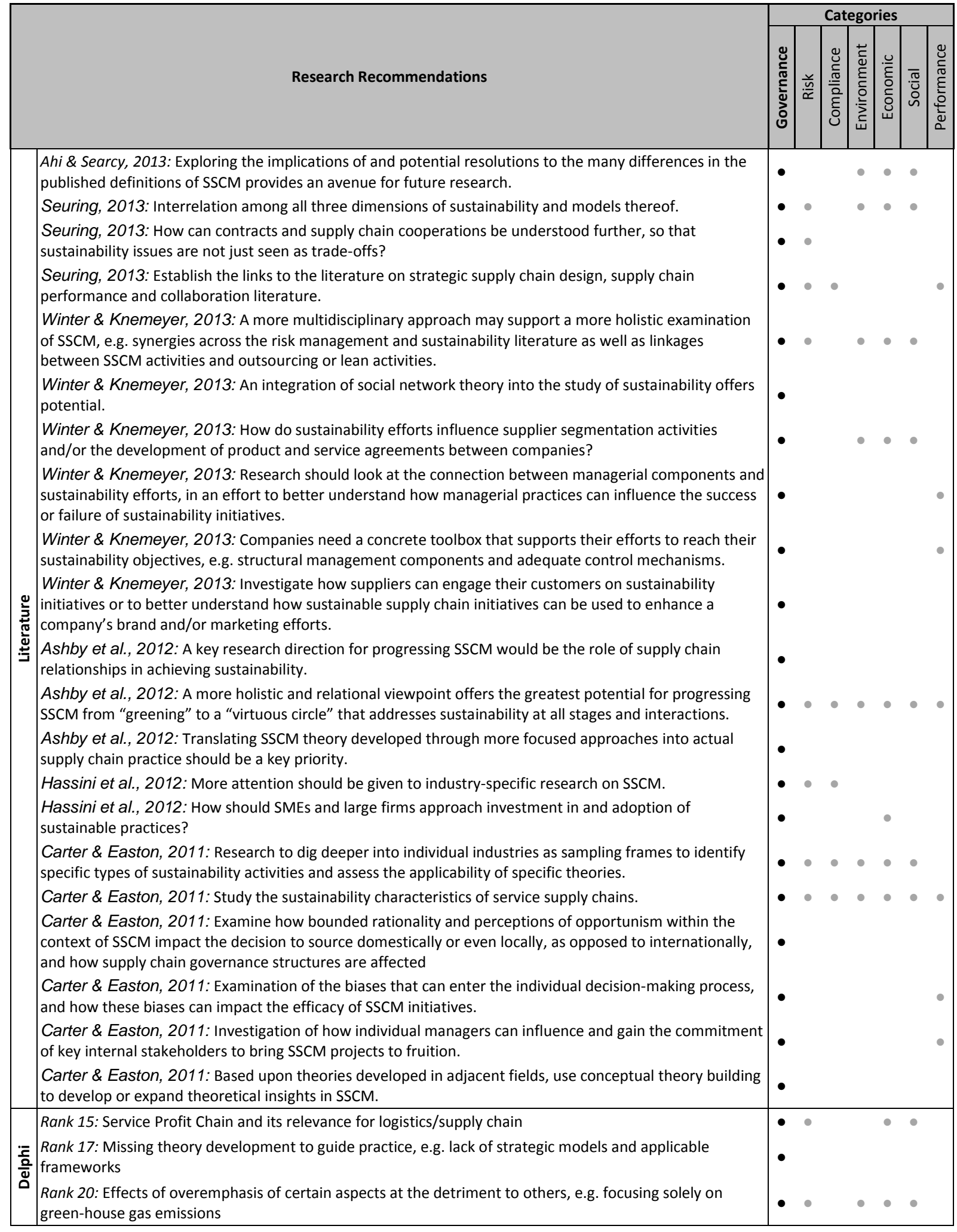


Thus far much research has focussed on single SC entities or isolated organisational functions, resulting in only limited understanding with regard to the requirements for a more holistic adoption of SSCM and its associated benefits (Rao \& Holt, 2005; Winter \& Knemeyer, 2013). There is an increasing realisation that researchers need to develop practical SSCM artefacts and guide SC practice through strategic models and frameworks (Rank 17). This mirrors the call for translations of SSCM theory into practice (Ashby et al., 2012) including structural management components and control mechanisms (Winter \& Knemeyer, 2013). Research aimed at providing practically applicable models and frameworks requires suitable reference material, targeted design activities, and rigorous testing. There still appears to be a lack of understanding regarding SC practices that can foster sustainable development (Pagell \& Wu, 2009) and common standards are often missing (KPMG, 2011). A resulting research avenue is to examine the transitional stages that a $S C$ is likely to move through towards a holistic sustainability orientation. Sustainable development, due to its very nature and aims, has to be seen as a long-term commitment which does not necessarily lend itself to a quick transition. Structured approaches have been suggested as useful tools to guide SCs on their path towards sustainability (Boone et al., 2009; Lockamy, Childerhouse, Disney, Towill, \& McCormack, 2008; Reefke, Sundaram, \& Ahmed, 2010). Research needs to provide a better systemic understanding of SSCM to drive such endeavours. Useful insights may be gained from related fields, i.e. SSCM theory could be expanded through conceptual theory building (Carter \& Easton, 2011). Seuring (2013) describe valuable links to literature on SC strategy, design, performance, and collaboration. Exploring the concepts of life cycle analysis and closed-loop SCs could lead to a more connected view of sustainability in SCs (Ashby et al., 2012), especially in regard to designing sustainable SC networks (Eskandarpour et al., 2015). Connections to concepts such as the circular economy can also be drawn which holds the potential to enhance SSCM practices (Genovese et al., 2015). Winter \& Knemeyer (2013) see furthermore the potential to integrate insights from social network theory while synergies are also likely with risk management, outsourcing, and lean management.

\subsubsection{Risk Management}

The need for managing risk, future proofing, and managing uncertainties came through much more strongly in the Delphi study whereas it was less pronounced in the literature synthesis (Table 16). Overall this indicates a strong need for more research in this area. Investigating the future of SCs with regard to long-term outlook and restructuring needs was rated second highest by the experts. This is closely related to studying future SC trends and developments (Rank 11) and the need to better understand long-term effects and special requirements of long-distance SCs (Rank 12). Investigations into future SC trends and requirements could be accomplished through interviews with SC experts or group communication methods. Closely aligned to these suggestions is the call for more industryspecific research (Carter \& Easton, 2011; Hassini et al., 2012). Industry-specific findings could be derived by collating the insights from multiple case studies targeting a diverse range of SC environments. Cross-comparisons would support the identification of common characteristics as well as unique features that are, for example, industry or layout specific. Surveys across multiple industry 
types, company sizes, and locations could aid confirmatory research supported by the triangulation of results.

Table 16: Risk Management Research Opportunities

\begin{tabular}{|c|c|c|c|c|c|c|c|c|}
\hline \multirow{2}{*}{\multicolumn{2}{|c|}{ Research Recommendations }} & \multicolumn{7}{|c|}{ Categories } \\
\hline & & 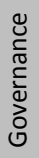 & $\frac{. \breve{s}}{x}$ & 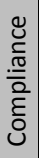 & 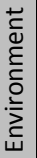 & 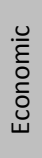 & $\frac{\bar{\pi}}{\overline{0}}$ & 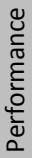 \\
\hline 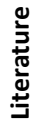 & $\begin{array}{l}\text { Hassini et al., 2012: Address inventory management within sustainable supply chains since traditional } \\
\text { inventory models focus on economic aspects. }\end{array}$ & $\bullet$ & $\bullet$ & & & $\bullet$ & & $\bullet$ \\
\hline \multirow{4}{*}{ 등 } & Rank 2: Future of supply chains, e.g. long-term outlook and restructuring needs & - & $\bullet$ & & & & & \\
\hline & Rank 10: Energy availability, e.g. peak oil and dependence on petrochemicals of supply chains & & • & & - & - & & \\
\hline & Rank 11: Future trends and developments in supply chains & - & $\bullet$ & - & & & & \\
\hline & $\begin{array}{l}\text { Rank 12: Long-term effect of sustainability movement in case of long supply chains and resulting special } \\
\text { requirements }\end{array}$ & - & & - & & & & - \\
\hline
\end{tabular}

Sustainability developments are confronted with many uncertainties especially when considering a network of companies, all subject to different regulations, market environments, competitive forces, and resulting strategic priorities. Investigating volatilities regarding the availability and prices of fuel and energy are suggested here (Rank 10). Such investigations are relevant since traditional SC practices are often based on the availability of cheap transport and energy, neglecting the importance of related efficiencies (Halldórsson \& Kovács, 2010). From a practical point of view, SCs need to ensure an adequate supply of energy and research findings in this regard could provide additional justifications for investments into SSCM. The need for a better understanding regarding the suitability of transportation practices and logistics to support SSCM has also previously been raised (Carter \& Easton, 2011; Dey et al., 2011; Halldórsson, Kotzab, \& Skjøtt-Larsen, 2009).

\subsubsection{Compliance}

Neither the literature synthesis nor the Delphi study have any emphasis on compliance as can be readily seen in Table 17. This could be attributed to the fact that (a) compliance is a necessity and/or (b) most developed nations have already addressed compliance requirements in their own backyard. But it is clear when considering a SC as a whole, potentially spanning economies in different phases, that many aspects of the SC may not be compliant and research does need to be conducted in compliance management. The topic of ' $\mathrm{CO}_{2}$ emissions and carbon footprints' obtained the lowest importance rating despite the attention it has received in recent years and the potentially large impacts of SCs (CSCMP, 2008; World Economic Forum, 2009). The research opportunity on onesided sustainability discussions (Rank 20) needs to be noted in this regard. Such one-sided attention may have been given to the issue of $\mathrm{CO}_{2}$ emissions which, as suggested by the Delphi panel, may have diverted attention away from other important matters. Hence, while studies into specific areas are certainly warranted, researchers should bear in mind the interconnected nature of SSCM. The relationship between regulatory compliance and economic performance across members of a supply 
chain has been highlighted by Carter \& Easton (2011). A holistic view with a focus on relations and influences in the SC holds great potential for progressing the understanding of SSCM (Ashby et al., 2012; Carter \& Easton, 2011). System dynamics modelling presents a viable research approach in this context. This is especially warranted for the investigation of time considerations, e.g. long term effects and delays (Georgiadis \& Besiou, 2008).

Table 17: Compliance Research Opportunities

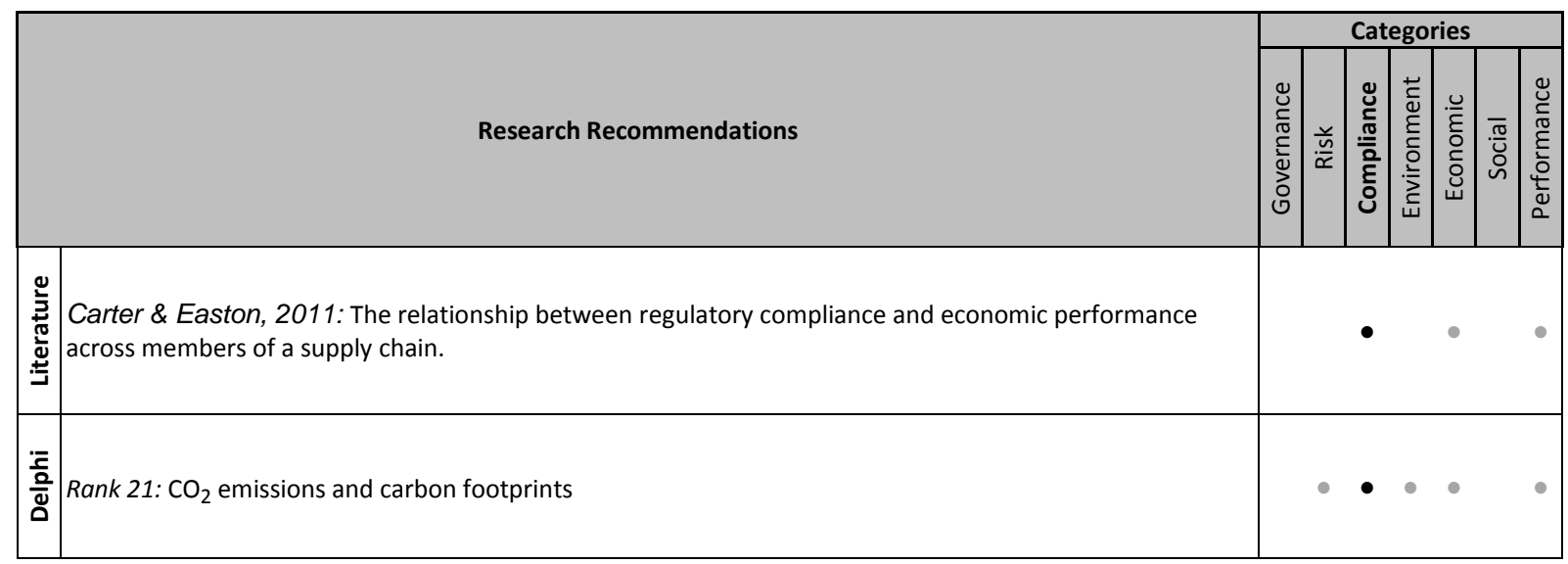

\section{Conclusion}

This study was motivated by the requirements to illuminate the multiple facets of practices that can support SSCM and to provide a foundation for SSCM scholars to address the apparent lack of theory (Carter \& Easton, 2011; Wagner \& Svensson, 2010; Winter \& Knemeyer, 2013). Thus, the objectives were to (1) develop themes that are central to the practice and research of SSCM and (2) to develop a research agenda for the field. In contrast to pure review studies, a much wider approach was taken in order to address these objectives. Review and synthesis of literature were combined with the advantages of a Delphi. Starting from open-ended questions, the insights and opinions of experts were gathered and further refined and evaluated in two stages.

Based on the objectives and the selected approach, this paper makes several contributions: Firstly, key SSCM themes are identified within the categories of planning, execution, coordination, and collaboration. Secondly, opportunities for enquiries in SSCM are gathered and organised into a research agenda using the following categories: governance, risk, compliance, sustainability dimensions (economic, environmental, and social), and performance management. Thirdly, the Delphi method facilitated an evaluation of SSCM themes and research recommendations in terms of importance. Discussions show how the overall study findings complement and extend existing literature in the field. New insights into potential dependencies between factors and their influence on the success of SSCM are provided.

Due to the flexible and exploratory nature of this Delphi, the identification of SSCM themes and research opportunities may be regarded incomplete while the importance evaluations may be seen as 
representative only for this particular group of experts. However, as documented in this paper, a rigorous process was followed based on seminal Delphi literature ensuring research validity and reliability. Additionally, the combination of the Delphi with the literature synthesis widened the reach of this study resulting in more complete and meaningful contributions. The outcomes of this study can be used in a prescriptive manner in order to inform practical applications of SSCM. They are useful as building blocks for a customised SSCM strategy and can guide SC managers in the prioritisation of activities and prerequisites for SSCM. Academics are advised to use the outlined research agenda as well as the themes in order to shape their own research priorities. The categorisations and importance rankings provide guidance on the thematic overlaps and relevance of these promising research avenues. 


\section{References}

Ahi, P., \& Searcy, C. (2013). A comparative literature analysis of definitions for green and sustainable supply chain management. Journal of Cleaner Production, 52, 329-341. doi:10.1016/j.jclepro.2013.02.018

Akkermans, H., \& Vos, B. (2003). Amplification in service supply chains: An exploratory case study from the telecom industry. Production and Operations Management, 12(2), 204-223. doi:10.1111/j.1937-5956.2003.tb00501.x

Arshinder, K. A., \& Deshmukh, S. G. (2008). Supply chain coordination: Perspectives, empirical studies and research directions. International Journal of Production Economics, 115(2), 316335. doi:10.1016/j.ijpe.2008.05.011

Ashby, A., Leat, M., \& Hudson-Smith, M. (2012). Making connections: a review of supply chain management and sustainability literature. Supply Chain Management: An International Journal, 17(5), 497-516. doi:10.1108/13598541211258573

Awaysheh, A., \& Klassen, R. D. (2010). The impact of supply chain structure on the use of supplier socially responsible practices. International Journal of Operations \& Production Management, 30(12), 1246-1268. doi:10.1108/01443571011094253

Badurdeen, F., Metta, H., \& Gupta, S. (2009). Taxonomy of research directions for sustainable supply chain management. IIE Annual Conference Proceedings, 1256.

Bansal, P., \& McKnight, B. (2009). Looking forward, pushing back and peering sideways: Analyzing the sustainability of industrial symbiosis. Journal of Supply Chain Management, 45(4), 26-37.

Bansal, S. (2009). Technology scorecards: Aligning it investments with business performance. Hoboken, New Jersey, USA: Wiley \& Sons.

Birkin, F., Polesie, T., \& Lewis, L. (2009). A new business model for sustainable development: An exploratory study using the theory of constraints in nordic organizations. Business Strategy and the Environment, 18(5), 277-290. doi:10.1002/bse.581

Blengini, G. A., \& Shields, D. J. (2010). Green labels and sustainability reporting: Overview of the building products supply chain in Italy. Management of Environmental Quality, 21(4), 477-493. doi:10.1108/14777831011049115

Boone, L. M., Colaianni, A. J., Hardison, J. R., Shafer, J. J., Shepherd, N. J., Ramaswamy, M. S., \& Wilkerson, T. H. (2009). The GAIA supply chain sustainability maturity model: LMI Research Institute.

Carter, C. R., \& Easton, P. L. (2011). Sustainable supply chain management: Evolution and future directions. International Journal of Physical Distribution \& Logistics Management, 41(1), 4662. doi:10.1108/09600031111101420

Carter, C. R., \& Rogers, D. S. (2008). A framework of sustainable supply chain management: Moving toward new theory. International Journal of Physical Distribution \& Logistics Management, 38(5), 360-387.

Cetinkaya, B. (2011). Developing a sustainable supply chain strategy Sustainable supply chain management (pp. 17-55). Berlin, Heidelberg: Springer

Chen, I. J., \& Paulraj, A. (2004). Towards a theory of supply chain management: The constructs and measurements. Journal of Operations Management, 22(2), 119-150.

Ching, C., Holsapple, C. W., \& Whinston, A. B. (1996). Toward IT support for coordination in network organizations. Information \& Management, 30(4), 179-199. doi:10.1016/0378-7206(95)000542

Colicchia, C., Melacini, M., \& Perotti, S. (2011). Benchmarking supply chain sustainability: Insights from a field study. Benchmarking: An International Journal, 18(5), 705-732. doi:10.1108/14635771111166839

Cooper, M. C., Ellram, L. M., Gardner, J. T., \& Hanks, A. M. (1997). Meshing multiple alliances. Journal of Business Logistics, 18(1), 67-90. 
Corbett, C. J., \& Klassen, R. D. (2006). Extending the horizons: Environmental excellence as key to improving operations. Manufacturing \& Service Operations Management, 8(1), 5-22.

Cox, E. P. (1980). The optimal number of response alternatives for a scale: A review. Journal of Marketing Research, 17(4), 407-422.

CSCMP. (2008). Tracking the green miles. Industry Week, 267(1), 60.

CSCMP. (2009). CSCMP's Supply Chain Management Process Standards (2nd ed., pp. 152): Council of Supply Chain Management Professionals.

Dalkey, N. C. (1969a). Analyses from a group opinion study. Futures, 1(6), 541-555.

Dalkey, N. C. (1969b). The Delphi method: An experimental study of group opinion (RM-5888-PR). Retrieved from Santa Monica, CA:

Dalkey, N. C., \& Helmer, O. (1963). An experimental application of the Delphi method to the use of experts. Management Science, 9(3), 458-467.

Day, J., \& Bobeva, M. (2005). A generic toolkit for the successful management of Delphi studies. The Electronic Journal of Business Research Methodology, 3(2), 103-116.

de Brito, M. P., Carbone, V., \& Blanquart, C. M. (2008). Towards a sustainable fashion retail supply chain in Europe: Organisation and performance. International Journal of Production Economics, 114(2), 534-553. doi:10.1016/j.ijpe.2007.06.012

Delbecq, A. L., Van de Ven, A. H., \& Gustafson, D. H. (1975). Group techniques for program planning: A guide to nominal group and Delphi processes. Glenview, IL: Scott, Foresman and Company.

Dey, A., LaGuardia, P., \& Srinivasan, M. (2011). Building sustainability in logistics operations: A research agenda. Management Research Review, 34(11), 1237-1259.

Dillman, D. A. (2007). Mail and internet surveys: The tailored design method: With new internet, visual, and mixed-mode guide (2nd ed.). Hoboken, NJ: John Wiley \& Sons.

Dodge, B. J., \& Clark, R. E. (1977). Research on the Delphi technique. Educational Technology, April, 58-60.

Elkington, J. (1998). Cannibals with forks: The triple bottom line of 21st century business. Gabriola Island, BC ; Stony Creek, CT: New Society Publishers.

Elkington, J. (2006). Governance for Sustainability*. Corporate Governance: An International Review, 14(6), 522-529. doi:10.1111/j.1467-8683.2006.00527.x

Engwall, L. (1983). Research note: Linguistic analysis of an open-ended questionnaire in an organizational study. Organization Studies, 4(3), 261-270. doi:10.1177/017084068300400304

Eskandarpour, M., Dejax, P., Miemczyk, J., \& Péton, O. (2015). Sustainable supply chain network design: An optimization-oriented review. Omega, 54, 11-32. doi:10.1016/j.omega.2015.01.006

Esty, D. C., \& Winston, A. S. (2006). Green to gold: How smart companies use environmental strategy to innovate, create value, and build competitive advantage. New Haven, CT: Yale University Press.

Evans, G. A., \& Heath, A. F. (1995). The measurement of left-right and libertarian-authoritarian values: A comparison of balanced and unbalanced scales. Quality \& Quantity, 29(2), 191-206. doi:10.1007/bf01101898

Friedman, H. H., \& Amoo, T. (1999). Rating the rating scales. Journal of Marketing Management, 9(3), 114-123.

Garriga, E., \& Melé, D. (2004). Corporate Social Responsibility Theories: Mapping the Territory. Journal of Business Ethics, 53(1-2), 51-71. doi:10.1023/b:busi.0000039399.90587.34

Genovese, A., Acquaye, A. A., Figueroa, A., \& Koh, S. C. L. (2015). Sustainable supply chain management and the transition towards a circular economy: Evidence and some applications. Omega. doi:10.1016/j.omega.2015.05.015 
Georgiadis, P., \& Besiou, M. (2008). Sustainability in electrical and electronic equipment closed-loop supply chains: A System Dynamics approach. Journal of Cleaner Production, 16(15), 16651678. doi:10.1016/j.jclepro.2008.04.019

Global Reporting Initiative. (2011). Sustainability reporting guidelines Version 3.1. Amsterdam, The Netherlands: Global Reporting Initiative.

Gold, S., Seuring, S., \& Beske, P. (2010). The constructs of sustainable supply chain management a content analysis based on published case studies. Progress in Industrial Ecology, an International Journal, 7(2), 114-137. doi:10.1504/PIE.2010.036045

Halldórsson, Á., Kotzab, H., \& Skjøtt-Larsen, T. (2009). Supply chain management on the crossroad to sustainability: a blessing or a curse? Logistics Research, 1(2), 83-94. doi:10.1007/s12159009-0012-y

Halldórsson, Á., \& Kovács, G. (2010). The sustainable agenda and energy efficiency: Logistics solutions and supply chains in times of climate change. International Journal of Physical Distribution \& Logistics Management, 40(1/2), 5-13. doi:10.1108/09600031011018019

Harms, D., Hansen, E. G., \& Schaltegger, S. (2012). Strategies in sustainable supply chain management: An empirical investigation of large German companies. Corporate Social Responsibility and Environmental Management, 20(4), 205-218. doi:10.1002/csr.1293

Hassini, E., Surti, C., \& Searcy, C. (2012). A literature review and a case study of sustainable supply chains with a focus on metrics. International Journal of Production Economics, 140(1), 69-82. doi:10.1016/j.jpe.2012.01.042

Hasson, F., Keeney, S., \& McKenna, H. (2000). Research guidelines for the Delphi survey technique. Journal of Advanced Nursing, 32(4), 1008-1015.

Hill, K. Q., \& Fowles, J. (1975). The methodological worth of the Delphi forecasting technique. Technological Forecasting and Social Change, 7(2), 179-192. doi:Doi: 10.1016/00401625(75) $90057-8$

Hsu, C.-C., \& Sandford, B. A. (2007). The Delphi technique: Making sense of consensus. Practical Assessment, Research \& Evaluation, 12(10), 1-8.

Jayaraman, V., Klassen, R., \& Linton, J. D. (2007). Supply chain management in a sustainable environment. Journal of Operations Management, 25(6), 1071-1074.

Ketokivi, M., \& Mantere, S. (2010). Two Strategies for Inductive Reasoning in Organizational Research. Academy of Management Review, 35(2), 315-333.

Kilger, C., Reuter, B., \& Stadtler, H. (2008). Collaborative Planning. In H. Stadtler \& C. Kilger (Eds.), Supply chain management and advanced planning: Concepts, models, software, and case studies (4th ed., pp. 556). Berlin, Germany: Springer.

Kleindorfer, P. R., Singhal, K., \& Van Wassenhove, L. N. (2005). Sustainable operations management. Production and Operations Management, 14(4), 482-492.

KPMG. (2011). KPMG international corporate responsibility reporting survey 2011 Retrieved from Amsterdam, The Netherlands:

Lambert, D. M., \& Cooper, M. C. (2000). Issues in supply chain management. Industrial Marketing Management, 29(1), 65-83.

Lee, H. L. (2004). The triple-A supply chain. Harvard Business Review, 82(10), 102-112, 157.

Lee, H. L. (2010). Don't tweak your supply chain - rethink it end to end. Harvard Business Review, 88(10), 62-69.

Li, X., Chung, C., Goldsby, T. J., \& Holsapple, C. W. (2008). A unified model of supply chain agility: The work-design perspective. International Journal of Logistics Management, 19(3), 408 435. doi:10.1108/09574090810919224

Lieb, K. J., \& Lieb, R. C. (2010). Environmental sustainability in the third-party logistics (3PL) industry. International Journal of Physical Distribution \& Logistics Management, 40(7), 524-533. doi:10.1108/09600031011071984 
Linstone, H. A., \& Turoff, M. (2002). The Delphi method: Techniques and applications. Reading, MA: Addison-Wesley

Linton, J. D., Klassen, R., \& Jayaraman, V. (2007). Sustainable supply chains: An introduction. Journal of Operations Management, 25(6), 1075-1082.

Liu, C.-M., Vazquez-Brust, D. A., \& Sarkis, J. (2014). The roles of first and second tier suppliers in greening international supply chains. In D. A. Vazquez-Brust, J. Sarkis, \& J. J. Cordeiro (Eds.), Collaboration for sustainability and innovation: $A$ role for sustainability driven by the global south? A cross-border, multi-stakeholder perspective (Vol. 3, pp. 322): Springer Netherlands.

Lockamy, A., Childerhouse, P., Disney, S. M., Towill, D. R., \& McCormack, K. (2008). The impact of process maturity and uncertainty on supply chain performance: An empirical study. International Journal of Manufacturing Technology and Management, 15(1), 12-27.

Loughlin, K. G., \& Moore, L. F. (1979). Using Delphi to achieve congruent objectives and activities in a pediatrics department. Academic Medicine, 54(2), 101-106.

Ludwig, B. (1997). Predicting the future: Have you considered using the Delphi methodology? Journal of Extension, 35(5), 1-4.

Lummus, R. R., Vokurka, R. J., \& Duclos, L. K. (2005). Delphi study on supply chain flexibility. International Journal of Production Research, 43(13), 2687-2708.

Martino, J. P. (1972). Technological forecasting for industry and government. New York, NY: Elsevier.

Martino, J. P. (1983). Technological forecasting for decision making (2nd ed.). New York, NY: Elsevier.

McIntyre, K. (2007). Delivering sustainability through supply chain management. In D. Waters (Ed.), Global Logistics - New directions in supply chain management (pp. 245-260). London, England: Kogan Page.

Mentzer, J. T., DeWitt, W., Keebler, J. S., Min, S., Nix, N. W., Smith, C. D., \& Zacharia, Z. G. (2001). Defining supply chain management. Journal of Business Logistics, 22(2), 1-25.

Menzies, C., Martin, A., Koch, M., Trebuth, C., Esche, S., Heinze, T., . . . Stähle, P. (2007). Governance, risk management and compliance: Sustainability and integration supported by technology. Retrieved from

Meyr, H., Wagner, M., \& Rohde, J. (2008). Structure of advanced planning systems. In H. Stadtler \& C. Kilger (Eds.), Supply chain management and advanced planning: Concepts, models, software, and case studies (4th ed., pp. 556). Berlin, Germany: Springer.

Miles, M. B., \& Huberman, A. M. (1994). Qualitative data analysis: An expanded sourcebook (2nd ed.). Thousand Oaks, CA: Sage Publications.

Miller, L. E. (2006). Determining what could/should be: The Delphi technique and its application. Paper presented at the annual meeting of the Mid-Western Educational Research Association, Columbus, $\mathrm{OH}$, Columbus, $\mathrm{OH}$.

Mitchell, V. W. (1991). The Delphi technique: An exposition and application. Technology Analysis \& Strategic Management, 3(4), 333 - 358.

Moberg, C. R., Vitasek, K., Stank, T. L., \& Pienaar, A. (2008). Time to remodel. CSCMP's Supply Chain Quarterly(Quarter 3), 36-48.

Munro, D. A. (1995). Sustainability: Rethoric or reality? In T. C. Trzyna \& J. K. Osborn (Eds.), A sustainable world: Defining and measuring sustainable development (pp. 27-35). Sacramento, CA: IUCN - the World Conservation Union by the International Center for the Environment and Public Policy, California Institute of Public Affairs.

Murphy, P. R., \& Poist, R. F. (2003). Green perspectives and practices: A "comparative logistics" study. Supply Chain Management: An International Journal, 8(2), 122-131. doi:10.1108/13598540310468724

Narayanan, V. G., \& Raman, A. (2004). Aligning incentives in supply chains. Harvard Business Review, 82(11), 94-102, 149. 
Norman, W., \& MacDonald, C. (2004). Getting to the bottom of "triple bottom line". Business Ethics Quarterly, 14(2), 243-262.

Okoli, C., \& Pawlowski, S. D. (2004). The Delphi method as a research tool: An example, design considerations and applications. Information \& Management, 42(1), 15-29.

Pagell, M., \& Wu, Z. (2009). Building a more complete theory of sustainable supply chain management using case studies of 10 exemplars. Journal of Supply Chain Management, 45(2), 37-56. doi:10.1111/j.1745-493X.2009.03162.x

Preston, C. C., \& Colman, A. M. (2000). Optimal number of response categories in rating scales: Reliability, validity, discriminating power, and respondent preferences. Acta Psychologica, 104(1), 1-15. doi:10.1016/s0001-6918(99)00050-5

Prokesch, S. (2010). The sustainable supply chain. Harvard Business Review, 88(10), 70-72.

PwC. (2011). Puma's reporting highlights global business challenges. PwC World Watch, Issue 3.

Racz, N., Weippl, E., \& Seufert, A. (2010). A frame of reference for research of integrated governance, risk and compliance (GRC). In B. De Decker \& I. Schaumüller-Bichl (Eds.), Communications and multimedia security (Vol. 6109, pp. 106-117): Springer Berlin Heidelberg.

Ramos, T. R. P., Gomes, M. I., \& Barbosa-Póvoa, A. P. (2014). Planning a sustainable reverse logistics system: Balancing costs with environmental and social concerns. Omega, 48, 60-74. doi:10.1016/j.omega.2013.11.006

Rao, P., \& Holt, D. (2005). Do green supply chains lead to competitiveness and economic performance? International Journal of Operations \& Production Management, 25(9), 898-916. doi:10.1108/01443570510613956

Reefke, H., Sundaram, D., \& Ahmed, M. D. (2010). Maturity progression model for sustainable supply chains. In W. Dangelmaier et al. (Ed.), Lecture notes in business information processing (LNBIP) (Vol. 46, pp. 308-319). Berlin, Germany: Springer.

Reefke, H., \& Trocchi, M. (2013). Balanced Scorecard for Sustainable Supply Chains: Design and Development Guidelines. International Journal of Productivity and Performance Management, 62(8), 805-826.

Robinson, J. (2004). Squaring the circle? Some thoughts on the idea of sustainable development. Ecological Economics, 48(4), 369-384. doi:10.1016/j.ecolecon.2003.10.017

Rowe, G., Wright, G., \& Bolger, F. (1991). Delphi: A reevaluation of research and theory. Technological Forecasting and Social Change, 39(3), 235-251. doi:10.1016/00401625(91)90039-i

SAP AG. (2009). SAP Thought Leadership- an integrated approach to managing governance, risk, and compliance. Retrieved from

SAP AG. (2011). SAP supply chain management. Retrieved from http://www.sap.com/solutions/business-suite/scm/scm50.epx

Sarkis, J. (1998). Evaluating environmentally conscious business practices. European Journal of Operational Research, 107(1), 159-174. doi:10.1016/s0377-2217(97)00160-4

Sarmah, S. P., Acharya, D., \& Goyal, S. K. (2006). Buyer vendor coordination models in supply chain management. European Journal of Operational Research, 175(1), 1-15. doi:10.1016/j.ejor.2005.08.006

Saunders, C., Barber, A., \& Taylor, G. (2006). Food miles - comparative energy/emissions performance of New Zealand's agriculture industry. Retrieved from Christchurch:

Scheele, D. S. (2002). Reality construction as a product of Delphi interaction. In H. A. Linstone \& M. Turoff (Eds.), The Delphi method - techniques and applications (pp. 35-67). Reading, MA: Addison-Wesley.

Scheibe, M., Skutsch, M., \& Schofer, J. (2002). Experiments in Delphi methodology. In H. A. Linstone \& M. Turoff (Eds.), The Delphi method - techniques and applications (pp. 257-281). Reading, MA: Addison-Wesley. 
Schmidt, R., C. (1997). Managing Delphi surveys using nonparametric statistical techniques. Decision Sciences, 28(3), 763-774.

Schummer, T., \& Lukosch, S. (2013). Patterns for computer-mediated interaction: John Wiley \& Sons.

Selviaridis, K., \& Spring, M. (2010). The dynamics of business service exchanges: Insights from logistics outsourcing. Journal of Purchasing and Supply Management, 16(3), 171-184. doi:10.1016/j.pursup.2009.12.007

Seuring, S. (2013). A review of modeling approaches for sustainable supply chain management. Decision Support Systems, 54(4), 1513-1520. doi:10.1016/j.dss.2012.05.053

Seuring, S., \& Müller, M. (2008a). Core issues in sustainable supply chain management - a Delphi study. Business Strategy and the Environment, 17(8), 455-466. doi:10.1002/bse.607

Seuring, S., \& Müller, M. (2008b). From a literature review to a conceptual framework for sustainable supply chain management. Journal of Cleaner Production, 16(15), 1699-1710. doi:10.1016/j.jclepro.2008.04.020

Seuring, S., Müller, M., Westhaus, M., \& Morana, R. (2005). Conducting a literature review - the example of sustainability in supply chains. In H. Kotzab, S. Seuring, M. Müller, \& G. Reiner (Eds.), Research methodologies in supply chain management (pp. 91-106). Heidelberg, Germany: Physica-Verlag.

Sharp, A., \& McDermott, P. (2009). Workflow modeling: Tools for process improvement and applications development (2nd ed.): Artech House.

Simatupang, T. M., \& Sridharan, R. (2002). The Collaborative Supply Chain. The International Journal of Logistics Management, 13(1), 15-30.

Simatupang, T. M., \& Sridharan, R. (2005). An integrative framework for supply chain collaboration. The International Journal of Logistics Management, 16(2), 257-274. doi:10.1108/09574090510634548

Skjoett-Larsen, T., Thernøe, C., \& Andresen, C. (2003). Supply chain collaboration: Theoretical perspectives and empirical evidence. International Journal of Physical Distribution \& Logistics Management, 33(6), 531-549. doi:10.1108/09600030310492788

Stadtler, H. (2005). Supply chain management and advanced planning-basics, overview and challenges. European Journal of Operational Research, 163(3), 575-588. doi:10.1016/j.ejor.2004.03.001

Svensson, G. (2007). Aspects of sustainable supply chain management (SSCM): Conceptual framework and empirical example. Supply Chain Management: An International Journal, 12(4), 262-266.

Turner, M., \& Houston, P. (2009). Going green? Start with sourcing. Supply Chain Management Review, 13(2), 14-21.

Turoff, M. (1970). The design of a policy Delphi. Technological Forecasting and Social Change, 2(2), 149-171.

Uhl, N. P. (1971). Identifying institutional goals. Durham, NC: National Laboratory for Higher Education.

Ulschak, F. L. (1983). Human resource development: The theory and practice of need assessment. Reston, VA: Reston Publication.

von der Gracht, H. A., \& Darkow, I.-L. (2010). Scenarios for the logistics services industry: A Delphibased analysis for 2025. International Journal of Production Economics, 127(1), 46-59. doi:10.1016/j.jpe.2010.04.013

Wagner, B., \& Svensson, G. (2010). Sustainable supply chain practices: Research propositions for the future. International Journal of Logistics Economics and Globalisation, 2(2), 176-186. doi:10.1504/IJLEG.2010.032432

WCED. (1987). Our common future. Retrieved from New York, NY: 
Weber, C. L., \& Matthews, H. S. (2008). Food-Miles and the Relative Climate Impacts of Food Choices in the United States. Environmental Science \& Technology, 42(10), 3508-3513. doi:10.1021/es702969f

Williams, P. L., \& Webb, C. (1994). The Delphi technique: A methodological discussion. Journal of Advanced Nursing, 19(1), 180-186. doi:10.1111/j.1365-2648.1994.tb01066.x

Winter, M., \& Knemeyer, A. M. (2013). Exploring the integration of sustainability and supply chain management: Current state and opportunities for future inquiry. International Journal of $\begin{array}{llll}\text { Physical Distribution \& Logistics Management, 43(1), 18-38. } & \text {. }\end{array}$ doi:10.1108/09600031311293237

Wittstruck, D., \& Teuteberg, F. (2011). Understanding the Success Factors of Sustainable Supply Chain Management: Empirical Evidence from the Electrics and Electronics Industry. Corporate Social Responsibility and Environmental Management, 19(3), 141-158. doi:10.1002/csr.261

World Economic Forum. (2009). Supply chain decarbonization: The role of logistics and transport in reducing supply chain carbon emissions. Retrieved from Geneva, Switzerland:

Zhu, Q., \& Sarkis, J. (2006). An inter-sectoral comparison of green supply chain management in China: Drivers and practices. Journal of Cleaner Production, 14(5), 472-486.

Zhu, Q., Sarkis, J., Cordeiro, J. J., \& Lai, K.-H. (2008). Firm-level correlates of emergent green supply chain management practices in the Chinese context. Omega, 36(4), 577-591. doi:10.1016/j.omega.2006.11.009

Zikmund, W. G. (2003). Business research methods (7th ed.). Mason, OH: Thomson/South-Western. 